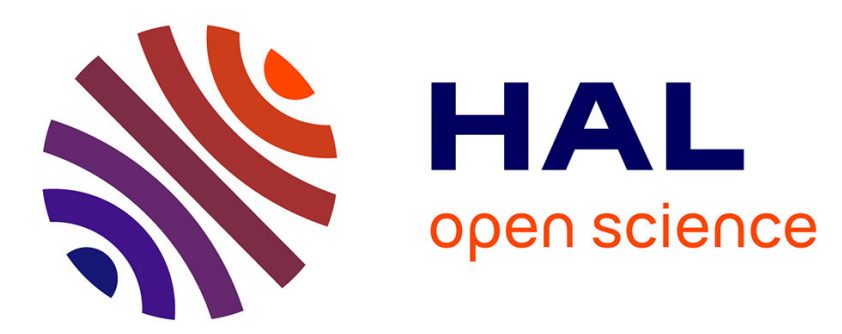

\title{
Submarine paleoseismology of the northern Hikurangi subduction margin of New Zealand as deduced from Turbidite record since $16 \mathrm{ka}$
}

\author{
Hugo Pouderoux, Jean-Noël Proust, Geoffroy Lamarche
}

\section{To cite this version:}

Hugo Pouderoux, Jean-Noël Proust, Geoffroy Lamarche. Submarine paleoseismology of the northern Hikurangi subduction margin of New Zealand as deduced from Turbidite record since 16 ka. Quaternary Science Reviews, 2014, 84, pp.116-131. 10.1016/j.quascirev.2013.11.015 . insu-00934455

\section{HAL Id: insu-00934455}

\section{https://hal-insu.archives-ouvertes.fr/insu-00934455}

Submitted on 23 Jan 2014

HAL is a multi-disciplinary open access archive for the deposit and dissemination of scientific research documents, whether they are published or not. The documents may come from teaching and research institutions in France or abroad, or from public or private research centers.
L'archive ouverte pluridisciplinaire HAL, est destinée au dépôt et à la diffusion de documents scientifiques de niveau recherche, publiés ou non, émanant des établissements d'enseignement et de recherche français ou étrangers, des laboratoires publics ou privés. 


\title{
SUBMARINE PALEOSEISMOLOGY OF THE NORTHERN HIKURANGI SUBDUCTION MARGIN OF NEW ZEALAND AS DEDUCED FROM TURBIDITE RECORD SINCE 16KA
}

\author{
Hugo Pouderoux ${ }^{1,2, *}$, Jean-Noël Proust ${ }^{1}$, Geoffroy Lamarche ${ }^{2}$ \\ ${ }^{1}$ Géosciences-Rennes, CNRS, Université Rennes1, Campus de Beaulieu, 35042, Rennes cedex, France. \\ E-mail: h.pouderoux@gmail.com; jean-noel.proust@univ-rennes1.fr \\ ${ }^{2}$ National Institute of Water and Atmospheric Research (NIWA), Private Bag 14-901, Wellington, \\ 6241, New Zealand. E-mail: g.lamarche@niwa.co.nz \\ * Present day address: Department of Geoscience, University of Calgary, 2500 University Drive NW, \\ Calgary, AB T2N 1N4, Canada
}

\section{KEYWORDS}

active margin; Poverty Bay; paleoearthquake; turbidite paleoseismology; synchronous slope failures; earthquake hazard assessment; peak ground acceleration

\begin{abstract}
Paleoseismic studies seek to characterise the signature of pre-historical earthquakes by deriving quantitative information from the geological record such as the source, magnitude and recurrence of moderate to large earthquakes. In this study, we provide a $\sim 16,000 \mathrm{yr}$-long paleo-earthquake record of the $200 \mathrm{~km}$-long northern Hikurangi Margin, New Zealand, using $\mathrm{cm}$-thick deep-sea turbidites identified in sediment cores. Cores were collected in strategic locations across the margin within three distinct morphological re-entrants - the Poverty, Ruatoria and Matakaoa re-entrants. The turbidite facies vary from muddy to sandy with evidence for rare hyperpycnites interbedded with hemipelagites and tephra. We use the Oxal probabilistic software to model the age of each turbidite, using the sedimentation rate of hemipelagite deduced from well-dated tephra layers and radiocarbon ages measurements on planktonic foraminifera.
\end{abstract}

Turbidites are correlated from one core to the other using similarity in sedimentary facies, petrophysical properties and ages. Results show that 46 turbidites are synchronous along the entire margin. Amongst them 41 are interpreted as originating from the upper continental slope in response to earthquake-triggered slope failures between $390 \pm 170$ to $16,450 \pm 310 \mathrm{yr}$ BP. Using wellestablished empirical relationships that combine peak ground acceleration, magnitude and location of earthquakes, we calculate that synchronous slope failures were triggered by the rupture of 3 of the 26 known active faults in the region, each capable of generating $M_{w} 7.3$ to 8.4 earthquakes - two are crustal reverse faults and one is the subduction interface. The $41 M_{w} \geq 7.3$ earthquakes occurred at an average recurrence interval of $\sim 400 \mathrm{yr}$ over the last $\sim 16,000 \mathrm{yr}$. Among them, twenty are interpreted as subduction interface earthquakes that occurred at a median recurrence interval of $\sim 800 \mathrm{yr}$, with alternating periods of high activity and low return times $(305-610 \mathrm{yr}$ ) and quiescence periods with high return times $(1480-2650 \mathrm{yr})$. Based on turbidite paleoseismology, we propose that subduction interface earthquakes were of lower magnitude during active periods $\left(M_{w}>7.5\right)$ than during quiescence periods $\left(M_{w} \geq 8.2\right)$.

\section{INTRODUCTION}

Submarine paleoseismology provides the means to derive reliable information on the spatial distribution and recurrence of prehistoric earthquakes in the marine environment from the 
sedimentary record. The method has been successfully applied at active margins (Adams, 1990; Goldfinger et al., 2003; 2007; Huh et al., 2004; Noda et al., 2008; Gracia et al., 2010; McHugh et al., 2011), in lakes (Strasser et al., 2006; Beck, 2009), and in intraplate domains (St-Onge et al., 2004). However, identification of earthquakes as the triggering mechanism of turbidites often remains equivocal despite careful sedimentological characterization (e.g. Gorsline et al., 2000; Nakajima and Kanai, 2000). Convincing interpretations have been obtained by demonstrating a synchronicity of trigger over long distances and across distinct sedimentary systems (Goldfinger et al., 2003; 2007; Gracia et al., 2010). In some cases, correlations with historical and instrumental records of earthquakes substantiate the interpretations, but in regions where written history does not exceed 200 years like in New Zealand, specific methodologies need to be developed to ascertain the earthquake origin of turbidites (Pouderoux et al., 2012a; 2012b; Barnes et al., 2013).

The northern Hikurangi subduction margin, east of New Zealand's North Island contains welldeveloped series of Quaternary turbidites (Lewis, 1973, 1980; Lewis et al., 2004; Pouderoux et al., 2012a). It is characterised by high sediment delivery (Hicks and Shankar, 2003; Hicks et al., 2004), and intense tectonic activity (Reyners and McGinty, 1999; Doser and Webb, 2003), which makes it an excellent location for marine turbidite paleoseismology studies. Three large morphological reentrants in the margin, the Poverty, Ruatoria and Matakaoa re-entrants (Fig. 1), concentrate gravity flow sedimentation (Lewis et al., 2004; Joanne et al., 2010; Pedley et al., 2010) and record a succession of turbidites emplaced since the Last Glacial Maximum (Pouderoux et al., 2012a). In Poverty re-entrant, Pouderoux et al. (2012b) demonstrated that most of the turbidites were triggered by paleo-earthquakes. However, their study focused on two cores recovered from a single sedimentary system and lacks the margin-scale embrace which may afford the characterisation of earthquakes of great magnitudes $\left(M_{W}>8\right)$ such as those generated along a subduction interface.

The present paper aims at establishing a calendar record of earthquakes that occurred along the northern Hikurangi Margin for the last $\sim 16,000 \mathrm{yr}$, at identifying the fault sources and estimating the magnitude of earthquakes at the origin of the turbidites. To do so, we use sedimentological and geomoprhological observations, chronostratigraphic correlations and peak ground acceleration attenuation models.

\section{BACKGROUND AND GEOLOGICAL SETTINGS}

\subsection{Morphological and tectonic settings}

The northern Hikurangi Margin (Fig. 1) comprises from east to west the 3500 m-deep Hikurangi Trough, a narrow sediment-starved accretionary prism, an unstable continental slope and a continental shelf supplied in sediments by the rivers of the Raukumara Peninsula (Lewis, 1980; Lewis and Pettinga, 1993; Collot et al., 1996). The margin extends northwards into the Kermadec subduction margin. Inland, west of the peninsula lies the rhyolitic Central Volcanic Region, which is the main source of geochemically distinct ash layers (tephra) that punctuate the terrestrial and subaqueous Quaternary sedimentary record of the North Island (Lowe et al., 2008). Three morphological re-entrants scar the continental slope (Fig. 1): (1) the $1500 \mathrm{~km}^{2}$ Poverty re-entrant which formed after successive margin collapses since $1500 \pm 500$ ka (Pedley et al., 2010); (2) the 3300 $\mathrm{km}^{2}$ Ruatoria re-entrant and associated Ruatoria Debris Avalanche formed $170 \pm 40 \mathrm{ka}$ ago (Collot et al., 2001); and (3) the $1000 \mathrm{~km}^{2}$ Matakaoa re-entrant located $\sim 100 \mathrm{~km}$ landward of the subduction margin and resulting from multiple mass transport events deposited between 1300 and 35 ka (Lamarche et al., 2008a; Joanne et al., 2010). The three re-entrants (thereafter named Poverty, Ruatoria or Matakaoa for simplicity) include gullies and canyons on the upper slope, mid-slope basins and trench basins, and represent independent Quaternary sedimentary systems.

The subduction of the Pacific Plate beneath the Australian Plate, at a present rate of $5 \mathrm{~cm} / \mathrm{yr}$ (DeMets et al., 1994; Beavan et al., 2002) is resulting in uplifting of the inland axial range of the 
Raukumara Peninsula at an estimated maximum rate of $3 \mathrm{~mm} / \mathrm{yr}$ (Reyners and McGinty, 1999; Wilson et al., 2007), and intense seismic activity along the margin (e.g. Webb and Anderson, 1998; Reyners and McGinty, 1999). Quantitative estimate of the interseismic coupling (Wallace et al., 2004; 2009), seismological studies (Reyners, 1993; 1998), tectonic investigations (Nicol and Wallace, 2009) and geomorphological characteristics (Collot et al., 1996) all contribute to the interpretation that the $600 \mathrm{~km}$-long Hikurangi Margin divides into three subduction interface segments, namely from south to north, the Wairarapa, Hawke's Bay and Raukumara segments. The change from accretion to erosion-dominated margin, North of Gisborne marks the transition from Hawke's Bay to Raukumara segments, where the study area is located. Empirical modelling suggests that rupture of the Raukumara or Hawke's Bay segment would result in $M_{w} 8.2-8.4$ earthquakes, whereas a simultaneous rupture of both segments would produce a $M_{w} 8.6$ earthquake, and that rupture of the entire Hikurangi Margin would result in a $M_{w} 8.8$ earthquake (Wallace et al., 2009; Stirling et al., 2012). Northwards, the Kermadec Margin may trigger $M_{w} \geq 8.5$ earthquakes that can affect the study area (Power et al., 2011). Seismic reflection surveys on the continental shelf have helped to identify a series of upper plate active faults (Barnes et al., 2002; Barnes and Nicol, 2004; Lewis et al., 2004; Fig. 1) and empirical relationships suggest some of these faults are capable of generating $M_{w} \geq 6.5$ earthquakes (Stirling et al., 2012; see also SM1).

The instrumental record of earthquakes in New Zealand since 1940 includes 298 earthquakes of $M_{w}>$ 5 in the study area, with only six of $\mathrm{M}_{\mathrm{w}} \geq 6.5$ (http://www.geonet.co.nz, as in December 2011). Two subduction interface earthquakes of $M_{w} 6.9-7.1$ were recorded in 1947 in the Poverty Bay area (Downes et al., 2000; Doser and Webb, 2003), and the $1931 \mathrm{M}_{\mathrm{w}} 7.8$ Napier upper plate earthquake is the largest and most damaging historic earthquake recorded in the area (Downes, 1995). Prehistoric $M_{w} \geq 7$ earthquakes over the last $9 \mathrm{kyr}$ are evidenced by uplifted marine terraces (Berryman, 1993; Wilson et al., 2006; 2007), subsided swamps (Cochran et al., 2006) and tsunami deposits (Goff and Dominey-Howes, 2009). Marine terraces uplifts at Pakarae river mouth and Mahia Peninsula are thought to be the result of near-shore fault ruptures (Wilson et al., 2007; Litchfield et al., 2010), namely the Gable End and Lachlan 3 faults (Fig. 1), that might have ruptured coevally. Sudden subsidence episodes at the origin of swamps flooding in Hawke's Bay were interpreted as the result of large offshore earthquakes either from ruptures of the Lachlan 3 fault or the subduction interface (Fig 1; Cochran et al., 2006). In Poverty, a $18 \mathrm{kyr}$ paleo-earthquake record based on turbidite deposition reveal a mean return time of $\sim 230$ years for moderate to large earthquakes and a $90 \%$ probability of occurrence ranging from 10 to 570 years (Pouderoux et al., 2012b). Probabilistic seismic hazard assessment suggests that earthquakes in the region with an associated Peak Ground Acceleration (PGA) of 0.3-0.5 g have a 500-year return time in the coastal area and that earthquakes with a PGA of 0.8-1.4 $\mathrm{g}$ have a 2500 year average return time (Stirling et al., 2012).

\subsection{Sedimentation patterns and turbidites deposition}

The ubiquitous gravity flow sedimentation of the northern Hikurangi Margin ranges from fine turbidites deposited on mid-slope basins to margin-scale debris avalanches (Lewis, 1973; Collot et al., 2001; Lamarche et al., 2008a; Mountjoy and Micallef, 2011; Pouderoux et al., 2012a). Quaternary sedimentation is characterised by interlayering of turbidites and hemipelagites infilling slope and trench basins (Lewis, 1980; Lewis and Pettinga, 1993; Lamarche et al., 2008b; Paquet et al., 2011). Over the last $\sim 18 \mathrm{kyr}$, accumulation rates in mid-slope basins and in the Hikurangi Trough range from $\sim 15$ to $\sim 110 \mathrm{~cm} / \mathrm{ka}$ (Orpin, 2004; Orpin et al., 2006; Pouderoux et al., 2012a). The Waipaoa and Waiapu rivers (Fig. 1) provide most of the turbidite material, contributing to an annual sediment delivery of $70 \mathrm{Mt} / \mathrm{yr}$ off the Raukumara Peninsula (Hicks and Shankar, 2003). The present day sedimentation rate estimated from ${ }^{210} \mathrm{~Pb}$ activity decreases from $\sim 1,000 \mathrm{~cm} / \mathrm{ka}$ on the continental shelf to $\sim 100 \mathrm{~cm} / \mathrm{ka}$ in mid-slope basins (Alexander et al., 2010; Kniskern et al., 2010), but forest clearing during human settlement in New Zealand $500-700 \mathrm{yr}$ ago resulted in river sediment fluxes 
110 to $660 \%$ greater than during the Holocene interglacial period (McGlone and Wilmshurst, 1999; Kettner et al., 2007; Paquet et al., 2009).

Turbidites along the northern Hikurangi Margin are recognised as $\mathrm{cm}$-thick fining up sandy to silty beds rich in volcaniclastic debris, quartz and bioclasts (Pouderoux et al., 2012a; Fig. 2). Few debrites, characterised by $<35 \mathrm{~cm}$-thick chaotic silty-clay beds with sand to pebble size clasts are also recognised. These two lithotypes alternate with hemipelagites, which consists of $1-90 \mathrm{~cm}$-thick layers of olive-grey silty-clay, and tephra layers, composed of volcaniclastic debris, mainly glass shards and pumiceous lapilli, and arranged in $<10 \mathrm{~cm}$-thick silty beds (Table 1). Boundaries between lithotypes are usually sharp, except between turbidites tails and hemipelagites.

Turbidites tails and hemipelagites have similar grain-size and texture but differ by their colours, with hemipelagites being lighter than turbidites. Hemipelagites are better sorted than turbidites, with a characteristic single grain-size peak $<10 \mu \mathrm{m}$. The composition of the silty fraction in hemipelagites explains the colour variations with abundant volcaniclastic debris and low quartz content when compared to turbidites, which show abundant quartz and low volcaniclastic debris. The differences are confirmed by $\delta^{13} \mathrm{C}$ and $\mathrm{C} / \mathrm{N}$ values, with higher $\delta^{13} \mathrm{C}$ and lower $\mathrm{C} / \mathrm{N}$ in hemipelagites than in turbidites (Pouderoux et al., 2012b). Erosion at the base of turbidites is considered negligible for those deposited during the Holocene but common during the Late Pleistocene (Pouderoux et al., 2012a). Floods and volcanic eruptions may have occasionally triggered turbidity currents in the area and resulted in the deposition of hyperyncites and primary monomagmatic turbidites (Pouderoux et al., 2012a). The majority of turbidites contains benthic foraminifers indicative of environments $\geq 150$ $\mathrm{m}$, suggesting an upper slope origin of the reworked material. In Poverty, 67 synchronous turbidites are interpreted as being originated from earthquake-triggered slope failures on the upper continental slope between $820 \pm 190$ and 17,730 \pm 700 yr BP (Pouderoux et al., 2012b).

\section{Methods}

\subsection{Sediment core analyses}

The present study is based on detailed stratigraphic correlation of sediment cores collected in Poverty, Ruatoria and Matakaoa (Fig. 1; Table 2). Cores were recovered from strategic locations to sample turbidites deposition since the Last Glacial Maximum (Proust et al., 2006). Four giant piston cores, 12 to $20 \mathrm{~m}$ long, were collected during the MD152 MATACORE voyage of R.V. Marion-Dufresne (Proust et al., 2006; 2008) in Poverty and Ruatoria in water depth ranging from 1400 to $3500 \mathrm{~m}$. In Poverty, MD06-3003 and MD06-3002 targeted two mid-slope basins in water depths of $1390 \mathrm{~m}$ and 2300 m respectively. In Ruatoria, MD06-3009 was collected in 2940 m water depth on top of the Ruatoria Debris Avalanche and $\sim 250 \mathrm{~m}$ above main sediment pathways. MD06-3008 was collected in $3520 \mathrm{~m}$ water depth in the Hikurangi Trough. Nine short piston cores were acquired onboard R.V. Tangaroa during research voyages TAN0314 (Carter et al., 2003) and TAN0810 (Lamarche et al., 2008b) in Ruatoria and Matakaoa in water depth ranging from 650 to $3400 \mathrm{~m}$. In Ruatoria, Tan0810-2 and -3 were collected on the upper continental slope in water depth of ca. $1080 \mathrm{~m}$, and Tan0810-6 was retrieved from the floor of the 3400 m-deep Hikurangi Trough. In Matakaoa, Tan0810-9 to -13 were collected within the channel/levee complex of the Matakaoa Turbidite System in water depth ranging from 1090 to $1260 \mathrm{~m}$ (Fig. 1). More specifically, Tan0810-9 and -12 were collected within the Matakaoa channel, Tan0810-10 on the left hand levee and Tan0810-11 and -13 on the right hand levee, all less than $2 \mathrm{~km}$ away from the channel. Tan0314-8 was collected within the deep-sea fan in $2030 \mathrm{~m}$ water depth.

Petrophysical analyses, including continuous gamma density, magnetic susceptibility and P-wave velocity, were obtained on split cores at $1 \mathrm{~cm}$ intervals using a Geotek Multi-Sensor Track. These measurements tied to the main lithofacies and lithofacies successions proved to be essential for core-to-core correlation. P-wave velocities tends to be underestimated $(1200-1500 \mathrm{~m} / \mathrm{s})$ but the 
downcore fluctuations, which were used for core-to-core correlations are similar to those in the density and magnetic susceptibility measurements as well as facies variations so that they are considered usable.

\subsection{Age model}

The stratigraphic framework is based on tephrochronology and $\mathrm{AMS}^{14} \mathrm{C}$ radiochronology with an average frequency of 0.7 to 2 ages per meter of core (Pouderoux et al., 2012a). Tephra were characterised by glass chemistry, mineralogy and their stratigraphic position and tied to the wellestablished regional charts of volcanic eruptions to get their precise calibrated ages (Shane, 2000; Lowe et al., 2008). The cores contain one to six tephra layers correlated to the nine large volcanic eruptions that occurred in the Central Volcanic Region. Radiocarbon dating was performed on handpicked mixed planktonic foraminifers from hemipelagite samples collected $0.7-1.0 \mathrm{~cm}$ below turbidite layers. Raw radiocarbon ages are calibrated using the Oxcal 4.1 software (Bronk Ramsey, 2008) with a regional reservoir age of $395 \pm 57 \mathrm{yr}(\Delta R=-5 \pm 57 \mathrm{yr})$ calculated from the published East Cape reservoir ages (Kalish, 1993; Higham and Hogg, 1995). A reservoir age of $800 \pm 110 \mathrm{yr}(\Delta R=400$ $\pm 110 \mathrm{yr}$ ) was applied for ${ }^{14} \mathrm{C}$ dates between 12,400 and $12,900{ }^{14} \mathrm{C}$ yr BP, as temporal variations of the reservoir age were identified during this period (Carter et al., 2008; Sikes et al., 2000).

We derive the age model for each core by interpolating hemipelagite sedimentation rates between time markers (tephra and ${ }^{14} \mathrm{C}$ ages) according to the $P_{-}$Sequence deposition model of the Oxcal 4.1 software, following the approach developed by Pouderoux et al. (2012b). The model provides the $68 \%$ and $95 \%$ probability age ranges $(1 \sigma$ and $2 \sigma)$ of each turbidite. In the following sections, ages are reported with $2 \sigma$ uncertainties. The $2 \sigma$ ages are considered reliable for Holocene turbidites as basal erosion is negligible, but the age may be overestimated during the Late Pleistocene when basal erosion is likely to have occurred (Pouderoux et al., 2012a).

\subsection{Correlation criteria}

We use four criteria to correlate turbidites from core to core (see SM2). (1) Tephra layers form absolute time-lines and robust stratigraphic markers. Their identification in distinct cores constitutes the first criteria for correlating events across the margin. (2) The estimated age of each turbidite is used as second criteria to make stratigraphic correlations between two tephra layers. However, because of the high number of turbidites and their age uncertainties, correlation from on core to another can be ambiguous at time. (3) We use the similarity in petrophysical properties (gamma density, magnetic susceptibility and P-wave velocity) and facies as third criteria, and (4) the thickness of turbidites and hemipelagite as fourth criteria to ascertain the correlations. Petrophysical properties are good correlation criteria (Patton et al., 2013; Goldfinger et al., 2012; Gracia et al., 2010) because turbidite coarse grain-size or volcaniclastic compositions typically result in high densities, magnetic susceptibilities and P-wave velocities and correlate well from core to core (Fig. 2).

\subsection{Terminology}

In this study, the term "turbidite event" (Tx) refers to a single, well-dated depositional episode underand overlain by hemipelagite. Stacked turbidites with no intertwined hemipelagite are considered as a single depositional event, as only the presence of hemipelagite guarantees the occurrence of significant time between two successive events. Two turbidites separated by a tephra layer represent two distinct events as usually tephra settle down within days to months after the volcanic eruptions (Wiesner et al., 1995).

"Basin events" represent synchronous turbidite events recorded in at least two cores in a single reentrant. Basin events are labelled $P x$ in Poverty, $R x$ in Ruatoria and $M x$ in Matakaoa, $x$ being the event sequential number in the re-entrant from the youngest to the oldest. 
Hikurangi "margin events" $(H x)$ are synchronous basin events recorded in at least two re-entrants along the northern Hikurangi Margin. The age of a margin event is determined by the intersection of the age ranges shared by the synchronous basin events. Non-correlative events are called "isolated events".

\section{RESULTS}

\subsection{Petrophysical properties of sediments}

The downcore variability in gamma density, magnetic susceptibility (MS) and P-wave velocity $\left(\mathrm{V}_{\mathrm{p}}\right)$ depends on sediment lithology and the alternation of hemipelagites, turbidites and tephra (Fig. 2; Table 3). Hemipelagites usually have constant low density $\left(1.1\right.$ to $\left.1.8 \mathrm{~g} / \mathrm{cm}^{2}\right), \mathrm{MS}(10$ to $60 \mathrm{SI})$ and $\mathrm{V}_{\mathrm{p}}$ (1225 to $1775 \mathrm{~m} / \mathrm{s}$ ). Turbidites have systematically higher density (1.2 to $2.2 \mathrm{~g} / \mathrm{cm}^{2}$ ), MS (10 to $120 \mathrm{SI}$ ) and $V_{p}(1225$ to $1950 \mathrm{~m} / \mathrm{s})$ with a decreasing trend from base to top. When preserved, tephra show values similar to turbidites, but higher than hemipelagites, with characteristic sharp variations at their base and top boundaries.

The boundary between turbidites and hemipelagites is progressive and difficult to identify using petrophysical properties alone. Turbidites show generally a progressive decrease while hemipelagites have stable values. Usually the decreasing trend of turbidite sequence is in good agreement with grain-size measurements, and coarser beds are noticed by a sharp increase of the density, MS and $V_{p}$ (Fig. 2).

\subsection{Age model and time-lines}

Cores in Ruatoria cover a continuous age range from $630 \pm 10 \mathrm{yr}$ BP to $15,360 \pm 70{ }^{14} \mathrm{C} \mathrm{yr}$, with the oldest sediments contained in cores MD06-3008 and MD06-3009 (Pouderoux et al., 2012a). In Matakaoa, cores from the turbidite plain (Tan0810-9 to -13) cover a continuous age range from 630 $\pm 10 \mathrm{yr}$ BP to $4,710 \pm 40{ }^{14} \mathrm{C} \mathrm{yr}$. In core Tan0314-8, two basal ${ }^{14} \mathrm{C}$ ages complement the tephra identification of Joanne et al. (2010), and show that the core contains a truncated record from 5,530 \pm 60 yr BP to $13,910 \pm 70{ }^{14} \mathrm{C}$ year.

Age models provide an age estimate for every single turbidite event (Fig. 3). Overall the average $2 \sigma$ age range is 410 years $(13-1141)$ in Ruatoria and 327 years $(13-970)$ in Matakaoa, comparable to the 300 year $(25-757) 2 \sigma$ age range calculated in Poverty (Pouderoux et al., 2012b). The ages of turbidite events in Ruatoria and Matakaoa correspond to the ages calculated at each corrected depth and ranges from $170 \pm 140$ to $18,150 \pm 150 \mathrm{yr} \mathrm{BP}$, similar to what was determined in Poverty ( 820 \pm 190 to $17,730 \pm 700$ yr BP). From 0 to 6 kyr, 11 cores (all but MD06-3002 and Tan0314-8) are usable to correlate turbidite events along the margin, while from 6 to $17 \mathrm{kyr}$, only five cores provide potential for turbidite events correlations.

\subsection{Core-to-core correlations}

\subsubsection{At basin scale}

In Ruatoria, turbidite events are thick, commonly $>10 \mathrm{~cm}$, and correlate well from the upper slope to the top of the debris avalanche and the Hikurangi Trough (Fig. 4; see also SM2 Fig. SM2.01). Cores on the upper slope (Tan0810-2 and -3) and on the top of the Ruatoria Debris Avalanche (MD06-3009) contain only basin events whereas the cores in the Hikurangi Trough (MD06-3008 and Tan0810-6) contain basin events and scattered isolated events. Two of these isolated events are primary monomagmatic turbidites deposited directly after the Taupo and Waimihia eruptions (Pouderoux et al., 2012a). We identified 30 basin events in Ruatoria, from $390 \pm 250$ to $15,940 \pm 580 \mathrm{yr}$ BP. Basin events younger than 6 ka (R1 to R14) correlate in all five cores, whereas events from 6 to $17 \mathrm{ka}$ (R15 to R30) correlate only in cores MD06-3008 and MD06-3009 (R15 to R30). The mean recurrence 
intervals of these 30 basin events is 520 years. Only MD06-3009 contains material older than 17 ka with a recurrence intervals of turbidite events of 97 years. This important difference in return time suggests that these turbidite events cannot be used as proxy for basin events for the period older than $\sim 17 \mathrm{kyr}$.

In Matakaoa, turbidite events are commonly $<5 \mathrm{~cm}$-thick, and often homogenised in the hemipelagite background because of severe bioturbation, hence a higher uncertainty in our interpretion of thin events as isolated or basin events than for Ruatoria and Poverty. We identify 19 basin events (M1 to M19) deposited in Matakaoa between $170 \pm 140$ and $16,400 \pm 780$ yr BP (Fig. 5; see also SM2 Fig. SM2.02). Basin events younger than 5 ka are only recognised in the turbidite plain (M1 to M9). Cores Tan0810-9, -10 and -13 mostly record basin events while cores Tan0810-11 and -12 are scattered with isolated events. Basin event M10 dated at 5,130 $290 \mathrm{yr}$ BP is the only event that correlates in the turbidite plain (Tan0810-10) and the deep-sea fan (Tan0314-8). No other events in the deep-sea fan correlate with upslope events because of the lack of age overlap in cores. Although this characterises them as isolated events, they likely represent basin events as the core was collected in the deep-sea fan at the outlet of the Matakaoa Turbidite System.

\subsubsection{At margin-scale}

Twenty-eight basin events are synchronous in two or more re-entrants over the last $16 \mathrm{kyr}$, and therefore fulfil the criteria of margin events (Fig. 6; see also SM2 Fig. SM2.03). Ten margin events are documented in the three re-entrants $(\mathrm{H} 3, \mathrm{H} 5, \mathrm{H} 8, \mathrm{H} 12, \mathrm{H} 23, \mathrm{H} 30, \mathrm{H} 33, \mathrm{H} 35, \mathrm{H} 41$, and H43; Table 4). $\mathrm{H} 4$ and $\mathrm{H} 6$ are identified from correlative basin events in Poverty and Ruatoria but also correlate to isolated events in Matakaoa. The remaining 16 margin events are only correlative in Poverty and Ruatoria (H7, H9-11, H13-14, H16, H18-19, H22, H26-28, H31-32, and H34; Table 4). All basin events in Ruatoria, except for the two youngest R1 and R2 dated at $390 \pm 250$ and $790 \pm 200 \mathrm{yr} \mathrm{BP}$, fulfil the criteria of margin events. Originally, R1 and R2 were not recognised as margin events since they did not correlate to basin events in Poverty. However, because R1 and R2 correlate to isolated events in Matakaoa and because material younger than $820 \mathrm{yr}$ BP was not retrieved in Poverty cores, we interpret them as margin events as all basin events in Ruatoria are margin events ( $\mathrm{H} 1$ and $\mathrm{H} 2$ in Table 4).

A further 15 basin events in Poverty, dated from 6 to 16 kyr (P24, P26, P30, P33, P38, P40, P49, P5761, P63, P65 and P66), correlate to 16 isolated events in core MD06-3008, and are interpreted as margin events ( $\mathrm{H} 15, \mathrm{H} 17, \mathrm{H} 2 \mathrm{O}, \mathrm{H} 21, \mathrm{H} 24, \mathrm{H} 25, \mathrm{H} 29, \mathrm{H} 36-40, \mathrm{H} 42$ and H44-46; Table 4). That specific period recorded in Ruatoria only by cores MD06-3008 and MD06-3009 is characterised by an unknown number of MD06-3008 isolated events not recognised as Ruatoria basin events due to a lack of data, as core MD06-3009 is located on a topographic high. In addition, during the period 0-6 kyr recorded in all cores, seven basin events not recorded in MD06-3009 (R1-2, R8-9, R11-12 and R14) fulfil the criteria of margin events. These observations confirm that the 15 correlated basin events in Poverty with isolated events in MD06-3008 are margin events.

Overall, the margin-scale correlation results in the identification of 46 margin events deposited from $390 \pm 170$ to $16,450 \pm 310 \mathrm{yr} \mathrm{BP}$, with an average age uncertainty of $\sim 170$ years (ranging from 6 to 400 years; Table 4).

\section{Discussion}

\subsection{Earthquake's origin of turbidites}

The associations of benthic foraminifers contained in basin and isolated events suggest a shelf edge origin of the reworked material within 150-200 m of water depth in Ruatoria and Poverty, and 150$600 \mathrm{~m}$ of water depth in Matakaoa (Pouderoux et al., 2012a; 2012b). Isolated events in the trench interpreted as margin events also rework material from the upper slope, which corroborates that 
turbidity currents originate from the upper slope and suggests a slope failure origin of most gravity flows. This suggestion is supported by the present day high state of instability of the Hikurangi Margin's upper slope associated with gas and fluids (Lewis and Marshall, 1996; Orpin, 2004; Faure et al., 2006), and high sediment supply during the Holocene (Hicks and Shankar, 2003; Addington et al., 2007; Lewis et al., 2004). At margin-scale, five margin events are interpreted as triggered by mechanisms other than slope failure: $\mathrm{H} 9, \mathrm{H} 22, \mathrm{H} 23$ and $\mathrm{H} 28$ which contain at least one hyperpycnite, and $\mathrm{H} 5$ which is a primary monomagmatic turbidite. The remaining 41 margin events are related to synchronous slope failures along the $100 \mathrm{~km}$-long northern Hikurangi Margin and all originated within 150-600 m of water depth since 16ka (Table 4; see also SM2 Fig. SM2.03).

Synchronicity of trigger over such wide areas is recognised as the most likely signature of large earthquakes in other regions of the world (Gracia et al., 2010; Goldfinger et al., 2003; 2012), although storms and tsunami waves may occasionally trigger gravity flows and slope failures (Mulder et al., 2001; Puig et al., 2004). Repeated storms have occurred along the northern Hikurangi Margin over the Late Holocene (Page et al., 2010), and are likely to have affected the seafloor by remobilising surficial sediments of the shelf or to have triggered sediment liquefaction (Lee and Edwards, 1986; Ma et al., 2010; Goldfinger et al., 2012). Puig et al. (2004) characterized sediment gravity flows directed down-canyon during storms on the California margin, and Mulder et al. (2001) described a storm-generated turbidite at $650 \mathrm{~m}$ water depth in a canyon head few months after a large historical storm in the Bay of Biscay. Furthermore, turbidity currents generated during storms are typically less voluminous and spread over smaller geographic areas than those triggered by earthquakes (Gorsline et al., 2000; Goldfinger et al., 2007; Blumberg et al., 2008). They also usually settle in water depth < $1000 \mathrm{~m}$ (Puig et al., 2004). The Matakaoa canyon's head contains a stack of recent $\mathrm{cm}$-thick turbidites recorded in $650 \mathrm{~m}$ water depth, sedimentologically similar to the storminduced turbidites found in the Bay of Biscay (Pouderoux, 2012; Pouderoux et al., 2012a). Even if confirmed along the Hikurangi Margin, these storm-related turbidites are likely to be restricted to canyon heads and not observed at water depth $>1000 \mathrm{~m}$ where we found deep-sea synchronous turbidites. Tsunami waves may also generate slope failures or turbidity currents directed down-slope and initiated on the continental shelf (Shanmugam, 2006). The largest historical tsunami affecting the region produced a run-up of $\sim 10 \mathrm{~m}$ north of Gisborne and was triggered by the local $M_{w} 7.1$ Gisborne earthquake of 25 March 1947 (Downes et al., 2000; Doser and Webb, 2003). Other tsunami run-ups of $10 \mathrm{~m}$ interpreted as likely generated by local earthquakes appear in the New Zealand paleo-tsunamis record (Goff and Dominey-Howes, 2009). The tsunami generated by the 23 May 1960 $M_{w} 9.5$ Chilean earthquake, the largest earthquake ever recorded worldwide, resulted in a $3 \mathrm{~m}$-high run-up at Gisborne and $4.5 \mathrm{~m}$ in Hawke's Bay (geonet.org.nz). This suggests that tsunamis potentially able to trigger slope failures are more likely to be generated by local earthquakes, which groundshaking is far more likely to trigger slope failures than the tsunamis wave itself.

Earthquakes are therefore the most likely triggering mechanism during the last sea-level highstand for the generation of synchronous slope failures at the origin of margin events, as inferred in other active margins (e.g. Noda et al., 2008; Gracia et al., 2010; Goldfinger et al., 2012). Storms and tsunamis are possibly secondary players during the marine trangression. Even if the average recurrence interval of margin events varies slightly between the Late Holocene highstand ( $440 \mathrm{yr}$ over the last $7.5 \mathrm{kyr}$ ) and the Late Pleistocene - Early Holocene marine transgression ( $375 \mathrm{yr}$ from 7.5 to $16 \mathrm{ka}$ ), it is possible that earthquake ground shaking was not the sole triggering mechanism of synchronous slope failures before $7.5 \mathrm{ka}$. It is extremely difficult to estimate the impact of storms and tsunamis waves on slope stability during the marine transgression. Consequently, if the turbidite record of the northern Hikurangi Margin is considered a good proxy for paleo-earthquakes during the Late Holocene and provides a calendar of 17 large earthquakes that occurred in the region between $390 \pm 170$ and $7480 \pm 120$ yr BP with an average return time of $\sim 440$ years, the Late Pleistocene Early Holocene part of this record incurs an increased uncertainty. Nevertheless, the turbidite record during the marine transgression could be use complementary to the Late Holocene highstand to 
constraint the earthquake hazard on the area, knowing that the recurrence intervals may be underestimated and the hazard overestimated.

\subsection{Source and magnitude estimation of paleo-earthquakes}

The 9 kyr-long coastal paleo-earthquake record is time correlative to margin events (Fig. 7). The $2 \sigma$ age range of margin events overlies the age of all marine terraces uplifts except one at Pakarae river mouth and one at Mahia peninsula. These uplifts were interpreted as the result of the rupture of near-shore Gable End and Lachlan 3 faults (Wilson et al., 2007; Litchfield et al., 2010). Conclusions are however sometimes equivocal: $\mathrm{H} 4$ and $\mathrm{H} 10$ are time correlative to the rupture of these two faults suggesting a simultaneous rupture of the two faults or a rupture of the subduction interface; $\mathrm{H} 1$ correlates with uplifts at the Pakarae river mouth and Mahia Peninsula and with a paleo-tsunami.

Over the last $7.5 \mathrm{kyr}$, ten margin events correlate to the paleo-earthquake record onland. These margin events are part of a group of 20 particularly large margin events identified over the last $16 \mathrm{ka}$ (Table 4; see also SM2 Fig. SM2.03), characterized by a $\sim 40 \mathrm{~cm}$-thick turbidite layer deposited on a topographic high in Ruatoria, $\sim 250 \mathrm{~m}$ above the main sediment pathways (core MD06-3009); such thickness is twice that of turbidites in other cores. They correspond to exceptionally voluminous turbidity currents triggered simultaneously in the three re-entrants. Such sedimentological evidences coupled with the systematic correlation with onland record are consistent with a triggering by subduction earthquakes initiated on the Raukumara segment of the subduction interface.

Slope failure triggering and turbidite deposition depend more on the shaking intensity felt on the slope than on the magnitude of the earthquake itself. The shaking intensity can be evaluated by calculating the peak ground acceleration (PGA) (Lee and Edwards, 1986; Douglas, 2000). The PGA threshold for slope failure and turbidity current generation in conditions similar to the upper slope of the northern Hikurangi Margin ranges from 0.08 to $0.6 \mathrm{~g}$ and more likely from 0.08 to $0.15 \mathrm{~g}$ (Lee et al., 1999; Lykousis et al., 2002; Strasser et al., 2007; Noda et al., 2008; Dan et al., 2009; see also SM3). By using the PGA empirical attenuation relationships of Cousins et al. (1999) and Si and Midoriwaka (1999), which are best suited for the region, we estimated the earthquake magnitude $\left(M_{w}\right)$ and the location of the hypocentre (depth and distance from the upper slope) of paleoearthquakes responsible for the triggering of upper slope failures. This enabled us to create isomagnitude maps and to identify areas where an earthquake of a given magnitude and origin has to occur to trigger synchronous slope failures and turbidity currents (Fig. 8; see also SM3 Fig. SM3). Superposing these isomagnitude maps over the known active faults (Stirling et al., 2012; Litchfield et al., in press) provides the means to infer the sources of paleo-earthquakes capable of generating our deep-sea turbidite record. (Table 5; see also SM3 Fig. SM3).

We disregard using a PGA threshold of $0.15 \mathrm{~g}$ for the triggering of turbidity currents as this would suggests that the 17 Late Holocene margin events were all subduction interface earthquakes, which is very unlikely (Table 5). A more reasonable PGA threshold between 0.08 and $0.1 \mathrm{~g}$ suggests that these events were associated with ruptures of upper plate faults or the subduction interface, all capable of generating $M_{w} \geq 7.3$. This latter interpretation is more consistent with our findings that only 10 out of these 17 margin events correspond to large subduction interface earthquakes. These values of PGA are also extremely closed to that determined along the Japan (Noda et al., 2008) and Algerian margins (Dan et al., 2009).

The 17 margin events provide a meaningful calendar of $M_{w} \geq 7.3$ paleo-earthquakes that have affected the region between $390 \pm 170$ and 7,480 \pm 120 yr BP : 10 subduction interface earthquakes and 7 upper plate earthquakes (Tables 4 and 5). The results show that only three out of the 26 known active fault sources recognized by Stirling et al. (2012) in the offshore northern Hikurangi Margin (faults 2, 6 and 7, namely the Raukumara subduction interface segment, Ruatoria South 1 and Areil Bank; Table 5) are responsible for this deep sea turbidite record. 


\subsection{Recurrence intervals of large earthquakes}

Our turbidite paleoseismology approach reveals that the recurrence interval (RI) of $M_{w} \geq 7.3$ earthquakes ranges from 150 to 1240 years with an average of 440 years during the Late Holocene (Figs. 9 and 10). Seismological modelling shows that the three active faults identified as the potential sources of our paleo-earthquakes have an empirical RI of rupture of 1300-1670, 3340, and 720 years (Table 5; see also SM1; Stirling et al., 2012). Assuming that upper plate faults rupture independently from the subduction interface (Stirling et al., 2012), the average RI of fault ruptures would be comprised between 390 and 460 years, which fits well with the 440 years RI of margin events. During the Late Pleistocene - Early Holocene, margin events had an average RI of 350 years, ranging from a few years to up to 1100 years, which is in good agreement with the estimated average RI of fault ruptures from Stirling et al. (2012).

The RI of the 10 large margin events triggered by subduction interface earthquakes varies from 370 to 2090 years during the Late Holocene with alternating periods of high and low $\mathrm{RI}$, and an average $\mathrm{RI}$ of 800 years. A similar pattern is recorded for the Late Pleistocene - Early Holocene period. Assuming that subduction interface earthquakes are the sole triggering mechanism of these large margin events over the last $16 \mathrm{kyr}$, this pattern of RI suggests two different tectonic regimes with periods of intense activity separated by periods of relative quiescence (Fig. 9). Such scenarios have been suggested by Berryman et al. (1989) for the Hikurangi Margin, Patton et al. (2009) for the Sumatra margin and Goldfinger et al. (2009; 2013) for the Cascadia margin. Active periods exhibit shorter durations (0.6-3 kyr-long) and drastically shorter RI (305-610 years) than quiescence ones (1.5-3.2 kyr-long with RI range of 1480-2650 years). These RIs differ from the predicted 1300-1670 years calculated using seismological modelling by Stirling et al. (2012). The latter RIs are closer to that observed during periods of quiescence than that during active periods. The RI and $\mathrm{M}_{\mathrm{w}}$ of Stirling et al. (2012) are maximum values determined from empirical relationships and represent the time needed for the subduction interface to accumulate enough strain to rupture the full length of the Raukumara segment. Active seismic periods recorded in the sedimentary record suggest that in a stable tectonic regime (convergence rate, slip rate, etc...), the deformation and energy released by the subduction interface may be partitioned with multiple ruptures generating earthquakes less that $\mathrm{M}_{\mathrm{w}} 8.2-8.4$.

Isomagnitude maps suggest that a $M_{w} 7.5-8$ earthquake on the subduction interface segment would be enough to generate a PGA of $0.08-0.1 \mathrm{~g}$ on the upper slope and therefore trigger simultaneous turbidity currents along the northern Hikurangi Margin (see SM3 Fig. SM3). Considering the constraint given by core MD06-3009 and the presence of turbidites on topographic highs, we propose that during active periods the Raukumara segment of the subduction interface produced regular large $M_{w} 7.5-8$ earthquakes. These earthquakes may not rupture the full length of the Raukumara segment or release the total accumulated strain. This is in good agreement with the two inferred moderate subduction interface earthquake $\mathrm{Mw} 7$ and 7.1 which affected the Gisborne district in 1947 (Doser and Webb, 2003).

\section{Conclusion}

This study presents the first chrono-stratigraphic correlation of deep-sea turbidites along the northern Hikurangi Margin of New Zealand, from the detailed description and age dating of sixteen sediment cores collected in the Poverty, Ruatoria and Matakaoa re-entrants. Age models provide a precise age estimate for every single turbidite deposited since the Last Glacial Maximum. The age of turbidites ranges from $170 \pm 140$ to $18,150 \pm 150 \mathrm{yr}$ BP.

Basin-scale correlations of turbidites result in the identification of 30 basin events (synchronous turbidites) deposited in Ruatoria between $390 \pm 250$ and 15,940 $\pm 580 \mathrm{yr}$ BP, and 19 basin events deposited in Matakaoa between $170 \pm 140$ and 16,400 \pm 780 yr BP. Previous studies have recognised 73 basin events in Poverty, deposited between $820 \pm 190$ and 17,730 \pm 700 yr BP. 
Margin-scale correlations result in the identification of 46 margin events (synchronous basin events) deposited from $390 \pm 170$ to $16,450 \pm 310 \mathrm{yr}$ BP, among which four are recognised as catastrophic floods deposits (hyperpycnites) and one a primary monomagmatic turbidite. The remaining 41 margin events are related to synchronous slope failures along the margin.

Earthquakes are the triggering mechanism of these slope failures during the sea-level highstand, and are also likely to be the main triggering mechanism during the marine transgression. The turbidite record of the northern Hikurangi Margin is therefore a good proxy for paleo-earthquakes, corroborated by the time correlation with onland paleo-earthquake evidences.

The use of empirical relationships evaluating the upper slope stability allows us to estimate magnitude $M_{w}$ and location (depth and distance from the upper slope) of paleo-earthquake. The 41 margin events correspond to $M_{w} \geq 7.3$ earthquakes that have affected the region from $390 \pm 170$ to $16,450 \pm 310 \mathrm{yr} \mathrm{BP}$, involving 3 of the 26 known active faults in the region (10\%). Recurrence interval deduced from turbidite chronology is similar to the estimated activity of these three active faults. Twenty margin events are interpreted as subduction interface earthquakes of $M_{w}>7.5$ and up to 8.4 affecting the three re-entrants and able to trigger coeval voluminous turbidity currents together with onland paleoseismic evidences.

Our study shows that large earthquake of $M_{w} \geq 7.3$ occurring on the northern Hikurangi Margin are more likely to occur with a RI of $200 \pm 100$ years, while large to great subduction interface earthquakes of $M_{w}>7.5$ to occur every $550 \pm 50$ years. RI of subduction interface earthquakes suggests alternating periods of intense activity with frequent but smaller earthquakes separated by periods of relative quiescence characterized by rare but more powerful earthquakes.

\section{ACKNOWLEDGMENTS}

This project was funded by the Centre National de la Recherche Scientifique - Institut National des Sciences de I'Univers (CNRS-INSU Research Program "Aléas, risques et catastrophes telluriques") and the New Zealand Ministry of Science and Innovation (previously Foundation for Research Science and Technology) through their program Paleoseismicity of the Alpine Fault and Hikurangi Margin (C01X0801). This study is part of a PhD undertaken at the Université de Rennes 1 (Géosciences Rennes) and NIWA, funded by a research grant from Ministère de l'Enseignement Supérieur et de la Recherche. The French Ministry of Foreign Affairs (French Embassy in Wellington) and the Université Européenne de Bretagne provided support funds for international travels. Gary Wilson facilitated access to the University of Otago's Geotek Multi-Track Sensor. Alan Orpin, Philip Barnes, Helen Neil, Helen Bostock (NIWA), and Kate Clark and Nichola Litchfield (GNS Science) contributed through numerous constructive discussions. The authors also thank Eulàlia Gràcia (Barcelona Centre for Subsurface Imaging) for her advices on the Oxcal software. Thanks to the two anonymous reviewers for their constructive reviews that helped us to improve the clarity of the paper.

\section{REFERENCES}

Adams, J., 1990. Paleoseismicity of the Cascadia subduction zone: evidence from turbidites off the Oregon-Washington Margin. Tectonics 9, 569-583.

Addington, L.D., Kuehl, S.A, McNinch, J.E., 2007. Contrasting modes of shelf sediment dispersal off a high-yield river: Waiapu River, New Zealand. Marine Geology 243, 18-30.

Alexander, C.R., Walsh, J.P., Orpin, A.R., 2010. Modern sediment dispersal and accumulation on the outer Poverty continental margin. Marine Geology 270, 213-226. 
Barnes, P.M., Bostock, H.C., Neil, H.L., Strachan, L.J., Gosling, M., 2013. A 2300-year paleoearthquake record of the southern Alpine Faut and Fiordland subduction zone, New Zealand, based on stacked turbidites. Bulletin of Seismological Society of America 103, 2424-2446, doi: 10.1785/0120120314.

Barnes, P.M., Nicol, A., 2004. Formation of an active thrust triangle zone associated with structural inversion in a subduction settings, eastern New Zealand. Tectonics 23, doi: 10.1029/2002TC001449.

Barnes, P.M., Nicol, A., Harrison, T., 2002. Late Cenozoic evolution and earthquake potential of an active listric thrust complex above the Hikurangi subduction zone, New Zealand. GSA Bulletin 114, 1379-1405.

Beavan, J., Tregoning, P., Bevis, M., Kato, T., Meertens, C., 2002. Motion and rigidity of the Pacific Plate and implications for plate boundary deformation. Journal of Geophysical Research, 107, B10, 2261, doi:10.1019/2011JB000282.

Beck, C., 2009. Late Quaternary lacustrine paleo-seismic archives in north-western Alps: Examples of earthquake-origin assessment of sedimentary disturbances. Earth-Science Reviews 96, 327-344.

Berryman, K., 1993. Age, height, and deformation of Holocene marine terraces at Mahia Peninsula, Hikurangi subduction margin, New Zealand. Tectonics 12, 1347-1364.

Berryman, K.R., Ota, Y., Hull, A.G., et al., 1989. Holocene paleoseismicity in the fold and thrust belt of the Hikurangi subduction zone, eastern North Island, New Zealand. Tectonophysics 163, 185-195.

Blumberg, S., Lamy, F., Arz, H.W., Echtler, H.P., Wiedicke, M., Haug, G.H., Oncken, O., 2008. Turbiditic trench deposits at the South-Chilean active margin: A Pleistocene-Holocene record of climate and tectonics. Earth and Planetary Science Letters 268, 526-539.

Bronk-Ramsey, C., 2008. Deposition models for chronological records. Quaternary Science Reviews, 27, 42-60.

Carter, L., Lamarche, G., Dunkin, M., Mitchell, J., Northcote, L., Wilcox, S., Kuehl, S., Addington, L., Kniskern, T., Romine, H., Brackley, H., Migeon, S., McNinch, J., Misalis, J., Scione, J., 2003. TAN0314 Research Voyage Report, unpublished NIWA Internal report, National Institute of Water and Atmospheric Research, Wellington, New Zealand.

Carter, L., Manighetti, B., Ganssen, G., Northcote, L., 2008. Southwest Pacific modulation of abrupt climate change during the Antarctic Cold Reversal - Younger Dryas. Palaeogeography, Palaeaoclimatology, Palaeoecology 260, 284-298.

Cochran, U., Berryman, K., Zachariasen, J., Mildenhall, D., Hayward, B., Southall, K., Hollis, C., Barker, P., Wallace, L., Alloway, B., Wilson, K., 2006. Paleoecological insights into subduction zone earthquake occurrence, eastern North Island, New Zealand. Geological Society of America Bulletin $118,1051-1074$.

Collot, J.Y., Delteil, J., Lewis, K.B., Davy, B., Lamarche, G., Audru, J.C., Barnes, P., Chanier, F., Chaumillon, E., Lallemand, S., deLepinay, B.M., Orpin, A., Pelletier, B., Sosson, M., Toussaint, B., Uruski, C., 1996. From oblique subduction to intra-continental transpression: Structures of the southern Kermadec-Hikurangi Margin from multibeam bathymetry, side-scan sonar and seismic reflection. Marine Geophysical Researches 18, 357-381.

Collot, J.Y., Lewis, K., Lamarche, G., Lallemand, S., 2001. The giant Ruatoria debris avalanche on the northern Hikurangi Margin, New Zealand: Result of oblique seamount subduction. Journal of Geophysical Research-Solid Earth 106, 19271-19297.

Cousins, W.J., Zhao, J.X., Perrin, N.D., et al., 1999. A model for the attenutation of peak ground acceleration in New Zealand earthquakes based on seismograph and accelerograph data. Bulletin of the New Zealand Society for Earthquake Engineering 32, 193-220. 
Dan, G., Sultan, N., Savoye, B., Deverchere, J., Yelles, K., 2009. Quantifying the role of sandy-silty sediments in generating slope failures during earthquakes: example from the Algerian margin. International Journal of Earth Sciences, 98, 769-789.

DeMets, C., Grodon, R. G., Argus, D. F., Stein, S., 1994. Effect of recent revisions to the geomagnetic reversal time scale on estimates of current plate motions. Geophysical Research Letters 21, 21912194.

Doser, D.I., Webb, T.H., 2003. Source parameters of large historical (1917-1961) earthquakes, North Island, New Zealand. Geophysical Journal International, 152, 795-832.

Douglas, J., 2000. A comprehensive worldwide summary of strong-motion attenuation relationships for peak ground acceleration and spectral ordinates (1969 to 2000). Engineering Seismology and Earthquake Engineering Report $n^{\circ} 01.1$ Imperial College of Science, Technology and Medecine, London, 144p.

Downes, G.L., 1995. Atlas of isoseismal maps of New Zealand earthquakes. Institute of Geological and Nuclear Sciences Monograph 11.

Downes, G., Webb, T., McSaveney, M., Darby, D., Doser, D., Chagué-Goff, C., Barnett, A., 2000. The March 25 and May 171947 Gisborne earthquakes and tsnunamis: implication for tsunami hazard for East Coast, North Island, New Zealand. Tsunami Risk Assessment Beyond 2000, Moscow Tsunami Workshop 2000.

Faure, K., Greinert, J., Pecher, I.A., Graham, I.J., Massoth, G.J., De Ronde, C.E.J., Wright, E.T., Olson, E.J., 2006. Methane seepage and its relation to slumping and gas hydrate at the Hikurangi marin, New Zealand. New Zealand Journal of Geology ad Geophysics 49, 503-516.

Goff, J., Dominey-Howes, D., 2009. Australasian paleotsunamis - Do Australia and New Zealand have a shared trans-Tasman prehistory? Earth-Science Reviews 97, 147-154.

Goldfinger, C., Morey, A.E., Nelson, C.H., Gutierrz-Pastor, J., Johnson, J.E., Karabanov, E., Chaytor, J., Eriksson, A., Shipboard Scientific Party., 2007. Rutpure lengths and temporal history of significant earthquakes on the offshore and north coast segments of the northern San Andreas Fault based on turbidite stratigraphy. Earth and Planetary Science Letters 254, 9-27.

Goldfinger, C., Ikeda, Y., Yeats, R.S., Ren, J., 2013. Superquakes and supercycles. Seismological Research Letters 84, doi: 10.1785/0220110135.

Goldfinger, C., Nelson, C.H., Johnson, J.E., Shipboard Sci, P., 2003. Deep-water turbidites as Holocene earthquake proxies: the Cascadia subduction zone and Northern San Andreas Fault systems. Annals of Geophysics 46, 1169-1194.

Goldfinger, C., Witter, R.C., Priest, G.R., Wang, K., Zhang, Y.J., Patton, J., Beeson, J. et al., 2009. Cascadia supercycles: Evidence of clustering and Holocene history of energy management from the long Cascadia paleoseismic record. Abstract AGU Chapman Conference on Giant Earthquakes and Their Tsunamis, Chile, May 2010.

Goldfinger, C., Nelson, C.H., Morey, A., Johnson, J.E., Gutierrez-Pastor, J., Eriksson, A.T., Karabanov, E., Patton, J., Gracia, E., Enkin, R., Dallimore, A., Dunhill, G., Vallier, T., 2012. Turbidite Event History: Methods and Implications for Holocene Paleoseismicity of the Cascadia Subduction Zone. USGS Professional Paper 1661-F, Reston, VA, U.S. Geological Survey, 184p, 64 Figures. http://pubs.usgs.gov/pp/pp1661f/

Gorsline, D.S., De Diego, T., Nava-Sanchez, E.H., 2000. Seismically triggered turbidites in small basins: Alfonso Basin, Western Gulf of California and Santa Monica Basin, California Borderland. Sedimentary Geology 135, 21-35. 
Gracia, E., Vizcaino, A., Escutia, C., Asioli, A., Rodes, A., Pallas, R., Garcia-Orellana, J., Lebreiro, S., Goldfinger, C.,. 2010. Holocene earthquake record offshore Portugal (SW Iberia): testing turbidite paleoseismology in a slow-convergent margin. Quaternary Science Reviews 29, 1156-1172.

Hicks, D.M., Gomez, B., Trustrum, N.A., 2004. Event suspended sediment characteristics and the generation of hyperpycnal plumes at river mouths: East Coast Continental Margin, North Island, New Zealand. Journal of Geology 112, 471-485.

Hicks, D.M., Shankar, U., 2003. Sediment yield from New Zealand rivers. NIWA chart, Miscellaneous series N.79. National Institute of Water and Atmospheric Research, Wellington, New Zealand.

Higham, T.F.G., Hogg, A.G., 1995. Radiocarbon dating of prehistoric shell from New Zealand and calculation of the Delta R value using fish otoliths. Radiocarbon 37, 409-416.

Huh, C.A., Su, C.C., Liang., W.T., Ling, C.Y., 2004. Linkages between turbidites in the southern Okinawa Trough and submarine earthquakes. Geophysical Research Letters, 31, L12304, doi:10/1029/2004GL019731.

Joanne, C., Collot, J.Y., Lamarche, G., Migeon, S., 2010. Continental slope reconstruction after a giant mass failure, the example of the Matakaoa Margin, New Zealand. Marine Geology 268, 67-84.

Kalish, J.M., 1993. Pre-bomb and post-bomb radiocarbon in fish ololiths. Earth and Planetary Science Letters 114, 549-554.

Kettner, A.J., Gomez, B., Syvitski, J.P.M., 2007. Modeling suspended sediment discharge from the Waipaoa River system, New Zealand: The last 3000 years. Water Resources Research 43.

Kniskern, T.A., Kuehl, S.A., Harris, C.K., Carter, L., 2010. Sediment accumulation patterns and finescale strata formation on the Waiapu River shelf, New Zealand. Marine Geology 270, 188-201.

Lamarche, G., Joanne, C., Collot, J.Y., 2008a. Successive, large mass-transport deposits in the south Kermadec fore-arc basin, New Zealand: The Matakaoa submarine instability complex. Geochemistry Geophysics Geosystems 9, Q04001, doi:10.1029/2007GC001843.

Lamarche, G., Orpin, A., Wilcox, S., Verdier, A.-L., Amyes, D., Woelz, S., McGill, K., 2008b. R.V. Tangaraoa TAN0810 Voyage Report: Transfer of extensional deformation, submarine instabilities and paleoearthquake proxy, unpublished NIWA Internal report $\mathrm{N}^{\circ} 135$, National Institute of Water and Atmospheric Research, Wellington, New Zealand.

Lee, H.J., Edwards, B.D., 1986. Regional assess offshore slope stability. Journal of Geotechnical Engineering-ASCE 112, 489-509.

Lee, H.J., Locat, J., Dartnell, P., Israel, K., Wong, F. et al., 1999. Regional variability of slope stability: application to the Eel margin, California. Marine Geology 154, 305-321.

Lewis, K.B., 1973. Ashes, turbidites, and rates of sedimentation on the continental slope off Hawke Bay. New Zealand Journal of Geology and Geophysics 16, 439-454.

Lewis, K.B., 1980. Quaternary sedimentation on the Hikurangi oblique-subduction and transform margin, New Zealand. In: Sedimentation in oblique slip mobile zone. Balance, P.F., Reading, H.G. (Eds). Special Publication International Association of Sedimentologists 4, 171-189.

Lewis, K.B., Marshall, B.A., 1996. Seep faunas and other indicators of methane-rich dewatering on New Zealand convergent margins. New Zealand Journal of Geology ad Geophysics 39, 181-200.

Lewis, K.B., Lallemand, S.E., Carter, L., 2004. Collapse in a Quaternary shelf basin off East Cape, New Zealand: evidence for passage of a subducted seamount inboard of the Ruatoria giant avalanche. New Zealand Journal of Geology ad Geophysics 47, 415-429. 
Lewis, K.B., Pettinga, J.R., 1993. The merging, imbricate frontal wedge of the Hikurangi Margin. In: Balance, P.F. (Ed.), South Pacific Sedimentary Basins. Sedimentary Basins of the World, vol. 2. Elsevier Science Publishers, Amsterdam, pp. 225-250.

Litchfield, N.J.; Van Dissen, R.; Sutherland, R.; Barnes, P.M.; Cox, S.C.; Norris, R.; Beavan, J.; Langridge, R.M.; Villamor, P.; Berryman, K.R.; Stirling, M.W.; Nicol, A.; Nodder, S.D.; Lamarche, G.; Barrell, D.J.A.; Pettinga, J.R.; Little, T.; Pondard, N.; Mountjoy, J. and Clark, K.J. (in press). A model of active faulting in New Zealand. New Zealand Journal of Geology and Geophysics.

Litchfield, N., Wilson, K., Berryman, K., Wallace, L., 2010. Coastal uplift mechanisms at Pakarae River mouth: Constraints from a combined Holocene fluvial and marine terrace dataset. Marine Geology $270,72-83$.

Lowe, D.J., Shane, P.A.R., Alloway, B.V., Newnham, R.M., 2008. Fingerprints and age models for widespread New Zealand tephra marker beds erupted since 30,000 years ago: a framework for NZINTIMATE. Quaternary Science Reviews 27, 95-126.

Lykousis, V., Roussakis, R., Alexandri, M., Pavlakis, P., Papoulia, I., et al., 2002. Sliding and regional slope stability in active margins: North Aegean Trough (Mediterranean). Marine Geology 186, 281298.

Ma, Y., Friedrichs, C.T., Harris, C.K., Donelson Wright, L., 2010. Deposition by seasonal wave- and current-supported sediment gravity flows interacting with spatially varying bathymetry : Waiapu shelf, New Zealand. Marine Geology 275, 199-211.

McGlone, M.S., Wilmshurst, J.M. 1999. Dating initial Maori environmental impacts in New Zealand. Quaternary International 59, 5-16.

McHugh, C.M., Seeber, L., Braudy, N., Cormier, M.H., Davis, M.B., Diebold, J.B., Dieudonne, N., Douilly, R., Gulick, S.P.S., Hornbach, M.J., Johnson III, H.E., Ryan Miskin, K., Sorlien, C.C., Steckler, M.S., Symithe, S.J., Templeton, J et al., 20101. Offshore sedimentary effects of the 12 January 2010 Haiti earthquake. Geology 39, 723-726.

Mountjoy, J.J., Micallef, A., 2011. Polyphase emplacement of a $30 \mathrm{~km} 3$ blocky debris avalanche and its role in slope-gully development. In: Submarine Mass Movements and Their Consequences, Advances in Natural and Technological Hazards Research 31, doi:10/1007/978-94-007-2162-3_19.

Mulder, T., Weber, O., Anschutz, P., Jorissen, F.J., Jouanneau, J.M., 2001. A few months-old stormgenerated turbidite deposited in the Capbreton Canyon (Bay of Biscay, SW France). Geo-Marine Letters 21, 149-156.

Nakajima, T., Kanai, Y., 2000. Sedimentary features of seismoturbidites triggered by the 1983 and older historical earthquakes in the eastern margin of the Japan Sea. Sedimentary Geology 135, 1-19.

Nicol, A., and Wallace, L.M., 2007. Temporal stability of deformation rates: comparison of geological and geodetic observations, Hikurangi subduction margin, New Zealand. Earth and Planetary Science Letters 258, 397-413.

Noda, A., TuZino, T., Kanai, Y., Furukawa, R., Uchida, J.I., 2008. Paleoseismicity along the southern Kuril Trench deduced from submarine-fan turbidites. Marine Geology 254, 73-90.

Orpin, A.R., 2004. Holocene sediment deposition on the Poverty-slope margin by the muddy Waipaoa River, East Coast New Zealand. Marine Geology 209, 69-90.

Orpin, A.R., Alexander, C., Carter, L., Kuehl, S., Walsh, J.P., 2006. Temporal and spatial complexity in post-glacial sedimentation on the tectonically active, Poverty Bay continental margin of New Zealand. Continental Shelf Research 26, 2205-2224. 
Page., M.J., Trustum, N.A., Orpin, A.R., Carter, L., Gomez, B., Cochran, U.A., Mildenhall, D.C., Rogers, K.M., Brackley, H.L., Palmer, A.S., Northcote, L., 2010. Storm frequency and magnitude in response to Holocene climate variability, Lake Tutira, North-Eastern New Zealand. Marine Geology 270, 30-44.

Paquet, F., Proust, J.N., Barnes, P.M., Pettinga, J.R., 2009. Inner-forearc sequence architecture in response to climatic and tectonic forcing since 150 ka: Hawke's Bay, New Zealand. Journal of Sedimentary Research 79, 97-124.

Paquet, F., Proust, J.N., Barnes, P.M., Pettinga, J.R., 2011. Controls on active forearc basin stratigraphy and sediment fluxes: The Pleistocene of Hawke Bay, New Zealand. GSA Bulletin 123, 1074-1096.

Patton, J.R., Goldfinger, C., Morey, A.E., Romsos, C., Black, B., Djadjadihardja, Y., Udrekh, 2013. Seismoturbidite record as preserved at core sites at the Cascadia and Sumatra-Andaman subduction zones. Natural Hazards and Earth System Sciences 13, 833-867.

Patton, J., Goldfinger, C., Morey, A.E., Djadjadihardja, Y., Hanifa, U, 201009. Temporal clustering, energy-state proxy, and recurrence of Holocene paleo-earthquakes in the region of the 2004 Sumatra-Andaman earthquake. Abstract AGU Chapman Conference on Giant Earthquakes and Their Tsunamis, Chile, May 2010.

Pedley, K.L., Barnes, P.M., Pettinga, J.R., Lewis, K.B., 2010. Seafloor structural geomorphic evolution of the accretionary frontal wedge in response to seamount subduction, Poverty Indentation, New Zealand. Marine Geology 270, 119-138.

Pouderoux, H., 2012. Gravity flow sedimentation and paleoseismicity of an active margin: the example of the Hikurangi subduction margin of New Zealand. Published Ph.D. thesis. Mémoire de Géosciences Rennes 142, 347p.

Pouderoux, H., Proust, J.N., Lamarche, G., Orpin, A., Neil, H., 2012a. Deep-sea sedimentation along the Hikurangi subduction margin (New Zealand) since the Last Glacial Maximum: characterisation, timing and origin of turbidites. Marine Geology, 295-298, 51-76.

Pouderoux, H., Lamarche, G., Proust, J-N., 2012b. Building a 18 000-year-long paleo-earthquake record from detailed deep-sea turbidite characterisation in Poverty Bay, New Zealand. Natural Hazards and Earth System Sciences 12, 1-25.

Power, W., Wallace, L., Wang, X., Reyners, M et al., 2011. Tsunami hazard posed to New Zealand by the Kermadec and southern New Hybrides subduction margins: an assessment based on plate boundary kinematics, interseismic coupling, and historical seismicity. Pure and Applied Geophysics, doi:10.1007/s00024-011-0299-x.

Proust, J-N., Lamarche, G., Migeon, S., Neil, H., and Shipboard Party, 2006. MD152/MATACORE Tectonic and climate controls on sediment budget. Les rapports de campagnes à la mer, Institut Paul Emile Victor, 107p.

Proust, J.N., Lamarche G., Migeon, S., Neil, H.L., 2008. Climate and tectonic changes in the ocean around New Zealand. EOS Transaction American Geophysical Union 89, 277-288.

Puig, P., Ogston, A.S., Mullenbach, B.L., Nittrouer, C.A., Parsons, J.D., Sternberg, R.W., 2004. Storminduced sediment gravity flows at the head of the Eel submarine canyon, northern California margin. Journal of Geophysical Research-Oceans 109.

Reyners, M., McGinty, P., 1999. Shallow subduction tectonics in the Raukumara peninsula, New Zealand, as illuminated by earthquake focal mechanisms. Journal of Geophysical Research-Solid Earth 104, 3025-3034.

Reyners, M., 1993, Lateral segmentation of the subducted plate at the Hikurangi Margin, New Zealand: seismological evidence: Tectonophysics, v. 96, p. 203-223. 
Reyners, M., 1998, Plate coupling and the hazard of large subduction thrust earthquakes at the Hikurangi subduction zone, New Zealand: New Zealand Journal of Geology and Geophysics, v. 41, p. 343-354.

Shane, P., 2000. Tephrochronology: a New Zealand case study. Earth Science Reviews 49, 223-259.

Shanmugam, G., 2006. The Tsunamite problem. Journal of Sedimentary Research 76, 718-730.

Si, H., Midorikwawka, S., 1999. New attenuation relations for peak ground acceleration and velocity considering effects of fault type and site conditions. Proceeding of $12^{\text {th }}$ World Conference on Earthquake Engineering. Translated in English in 2000. Journal of Structural and Construction Engineering, (Transaction of Architectural Institute of Japan) 523, 63-70.

Sikes, E.L., Samson, C.R., Guilderson, T.P., Howard, W.R., 2000. Old radiocarbon ages in the southwest Pacific Ocean during the last glacial period and deglaciation. Nature 405, 555-559.

St-Onge, G., Mulder, T., Piper, D.J.W., Hillaire-Marcel, C., Stoner, J.S., 2004. Earthquake and floodinduced turbidites in the Saguenay Fjord (Quebec): a Holocene paleoseismicity record. Quaternary Science Reviews 23, 283-294.

Stirling, M., McVerry, G., Gerstenberger, M., Litchfield, N., Van Dissen, R., Berryman, K., Barnes, P., Wallace, L., Bradley, B., Villamor, P., Langridge, R., Lamarche, G., Nodder, S., Reyners, M., Bradley, B., Rhoades, D., Smith, W., Nicol, A., Pettinga, J., Clark, K. and Jacobs, K., 2012. National Seismic Hazard Model for New Zealand: 2010 Update. Bulletin of the Seismological Society of America 102, 15141542.

Stirling, M., Rhoades, D., Berryman, K., 2002. Comparison of earthquake scaling relations derived from data of the instrumental and preinstrumental era. Bulletin of the Seismological Society of America 92, 812-830.

Strasser, M., Anselmetti, F.S., Fäh, D., Giardini, D., Schnellmann, M., 2006. Magnitudes and source areas of large prehistoric northern Alpine earthquakes revealed by slope failures in lakes. Geology 34 , 1005-1008, doi: 10.1130/G22784.A1.

Strasser, M., Stegmann, S., Bussmann, F., Anselmetti, F.S., Rick, B., Kopf, A., 2007. Quantifying subaqueous slope stability during seismic shaking: Lake Lucerne as model for ocean margins. Marine Geology 240, 77-97.

Wallace, L.M., Reyners, M., Cochran, U., Bannister, S., Barnes, P.M., Berryman, K., Downes, G., Eberhart-Phillips, D., Fagereng, A., Ellis, S., Nicol, A., McCaffrey, R., Beavan, R.J., Henrys, S., Sutherland, R., Barker, D.H.N., Litchfield, N., Townend, J., Robinson, R., Bell, R., Wilson, K., Power, W., 2009. Characterizing the seismogenic zone of a major plate boundary subduction thrust: Hikurangi Margin, New Zealand. Geochemistry Geophysics Geosystems 10, Q100006.

Wallace, L.M.J., Beavan, J., McCaffrey, R., Darby, D. et al., 2004. Subduction zone coupling and tectonic block rotations in the North Island, New Zealand. Journal of Geophysical Research 109, B12406, doi:10.1029/2004JB003241.

Webb, T.H., Anderson, H., 1998. Focal mechanisms of large earthquakes in the North Island of New Zealand: slip partitioning at an oblique active margin. Geophysical Journal International 134, 40-86.

Wiesner, M.G., Wang, Y., Zheng, L., 1995. Fallout of volcanic ash to the deep South China Sea induced by the 1991 eruption of Mount Pinatubo (Philippines). Geology 23, 885-888.

Wilson, K., Berryman, K., Cochran, U., Little, T., 2007. Early Holocene paleoseismic history at the Pakarae locality, eastern North Island, New Zealand, inferred from transgressive marine sequence architecture. Tectonics 26, TC4013, 18pp. 
Wilson, K., Berryman, K., Litchfield, N., Little, T., 2006. A revision of mid-late Holocene marine terrace distribution and chronology at the Pakarae River mouth, North Island, New Zealand. New Zealand Journal of Geology and Geophysics 49, 477-489. 


\section{Figure CAPtions}

Figure 1 - Morpho-tectonic settings of the northern Hikurangi Margin, New Zealand. Red dots show sediment cores used in this study. The present day average sediment deliveries of the three main rivers, which catchments are highlighted in grey shade, are indicated in dark grey (from Hicks and Shankar et al., 2003). White squares are locations of coastal paleo-earthquakes evidences in (A) Pakarae river mouth, (B) Mahia Peninsula, and (C) northern Hawke's Bay. Bold lines indicate the main earthquake sources identified by Stirling et al. (2012) and Litchfield et al. (in press) (see also SM1 Table SM1). Bold teeth-line indicates the subduction front. Insert: the Kermadec-Hikurangi margin with the Pacific (PAC) and the Australian (AUS) plates, the Wairarapa (W), Hawke Bay (HB) and Raukumara (R) regions, and the Central Volcanic Region (CVR). Dark arrow is relative plate motion at the plate boundary from Beavan et al. (2002).

Figure 2 - Characterisation of turbidites and hemipelagite from visual (photo), internal structures (X Ray), Geotek petrophysical properties (gamma density, magnetic susceptibility and P-wave velocity) and grain size (sand, silt and clay percentage). Peaks in grain size correspond to peaks in the Geotek; the turbidites' fining up trend is illustrated by the Geotek measurements.

Figure 3 - Example of the Oxcal age model from a giant piston core (MD06-3009) and two short piston cores (Tan0810-2 and -6), showing the sedimentation rate of hemipelagite through time. The $k$ parameter is used to define the regularity of the sedimentation rate along the core: the higher the $k$ parameter, the more linear the sedimentation rate and the smaller the turbidite age uncertainties. Since hemipelagite settles at an assumed roughly constant rate, the highest $k$ parameter was chosen for each core. All ages are plotted with their $2 \sigma$ age range.

Figure 4 - Simplified correlation diagram of turbidites between cores in Ruatoria (upper slope, Ruatoria Debris Avalanche and Hikurangi Trough). Detailed correlations in SM2 Fig. SM2.01. Dashed lines are tephra. Basin events are labelled Rx. The c. 6 ka boundary (thin black line) is the average basal boundary of short cores. Black stars on isolated events show events correlated to basin events in Poverty and indicated unrecognised basin events in Ruatoria (see text for details). Number on the left of logs are turbidite facies as in Table 1.

Figure 5 - Simplified correlation diagram of turbidites between cores in Matakaoa (channel and levees in the turbidite plain and fan). Detailed correlations in SM2 Fig. SM2.02. Cores are arranged upstream to downstream from left to right; see caption and legend in figure 4.

Figure 6 - Example of margin-scale correlation of turbidites using one core from Poverty, two from Ruatoria and two from Matakaoa. Each re-entrant is c. $100 \mathrm{~km}$ apart. Detailed correlations in SM2 Fig. SM2.03. Turbidites are indicated by basic core log, facies (number from 1 to 5) and Geotek petrophysical properties (density and magnetic susceptibility). See legend and caption in figure 4. Margin events are labelled $\mathrm{Hx}$. The age of tephra layers (purple) is reported in cal. yr BP.

Figure 7 - Temporal correlation between margin events and onland evidences of paleo-earthquakes from the Pakarae river mouth (A; Wilson et al., 2006; 2007), Mahia Peninsula (B; Berryman et al., 1993), and northern Hawke's Bay (C; Cochran et al., 2006), and paleo-tsunamis identified along the east coast of the North Island East Coast (Goff and Dominey-Howes, 2009). Purple bands are age range of correlated margin events. Large margin events interpreted as the record of subduction interface earthquakes are framed in red. 
Figure 8 - Examples of isomagnitude maps defining the area shaken by an earthquake of a given magnitude, which can trigger synchronous slope failures in the source areas of the turbidites (blue area in the upper slope). Grey dots show the location of sediment cores. Each map is generated from an empirical relationship that defines the Peak Ground Acceleration (PGA) from the magnitude, depth, distance and type of earthquakes (see SM3 for details). Faults capable of producing earthquake shaking large enough to generate turbidity currents in the source area are shown in bold red (epicentre shown by red dots) and summarized in Table 5. Blue dots are epicentres of earthquakes that cannot generated ground-shaking capable of generating turbidites in the source area. In each map, the isomagnitude $M_{w} 7.5$ is shown as an example of the methodology used to define the Mw 7.5 area. (A) Isomagnitude map built from the relationship of Cousins et al. (1999), labelled Eq. (1). PGA $=0.08 \mathrm{~g}$ is reached simultaneously in the upper slope of Poverty and Ruatoria for a $M_{w} \geq 6.5$ earthquake located between both re-entrants. This corresponds to the activity of only two upper plate faults (red bold lines). See SM3 Fig. SM3 for subduction interface earthquakes isomagnitude maps. (B) Isomagnitude map built from the relationship of Si and Midoriwaka (1999), labelled Eq. (2). $P G A=0.1 \mathrm{~g}$ is reached simultaneously in the three re-entrants for $M_{w} \geq 7.2$ earthquakes located between Poverty and Ruatoria. This corresponds to the rupture of the subduction interface. No upper plate faults can trigger synchronous slope failures in the three reentrants.

Figure 9 - Recurrence intervals (RI) of large paleo-earthquakes at the origin of margin events vs time. (A) RI of $M_{w} \geq 7.3$ earthquakes at the origin of the 41 margin events identified over the last c. $16.5 \mathrm{kyr}$ (grey line). Dots correspond to the average age of the margin event $\mathrm{Hx}$ vs the average time span since the last one. The recurrence intervals of $M_{w}>7.5$ earthquake at the origin of the 20 large margin events is indicated by dashed blue line. (B) Distribution of RI of $M_{w}>7.5$ earthquakes showing an alternation of active periods in light yellow with low RI and numerous earthquakes, and quiescence periods in light blue during which larger RI are noted (for each period, average RI are noted in italic and their duration noted in bold).

Figure 10 - Frequency diagrams of paleo-earthquakes during (A) the Late Holocene and (B) the Late Pleistocene - Early Holocene. The latter is likely to be underestimated due to uncertainties discussed in the paper. $M_{w}>7.5$ earthquakes correspond to large margin events and $M_{w} \geq$ 7.3 earthquakes to all margin events (see text for details). Histograms (grey bars) show the frequency of recurrence interval (RI) within each bin of 100 years, with their statistical distribution estimated for each centile (black line). The median RI of each plot is noted in white for histograms and in black for the statistical distribution (cross).

\section{TABLES}

Table 1 - Lithotype characteristics of deep-sea sediments along the northern Hikurangi Margin (summarized from Pouderoux et al., 2012a).

Table 2 - Location and characteristics of sediment cores used in this study. T: gravity flow deposits (turbidites); $\mathrm{H}$ : hemipelagite.

Table 3 - Range of petrophysical properties of hemipelagite and turbidites calculated from the cores.

Table 4 - Margin events $(\mathrm{Hx})$ modelled age deduced from basin events correlation in Poverty, Ruatoria and Matakaoa. 
857

858

859

860

861

862

Table 5 - Earthquake sources and estimated magnitude deduced from the overlap of isomagnitude maps (Fig. 8; see also SM3 Fig. SM3) and the known active faults complied by Stirling et al (2012). Different scenarios are considered according tothe two type of margin events, the three PGA thresholds for slope failures triggering and the two empirical relationships used to build isomagnitude maps. 


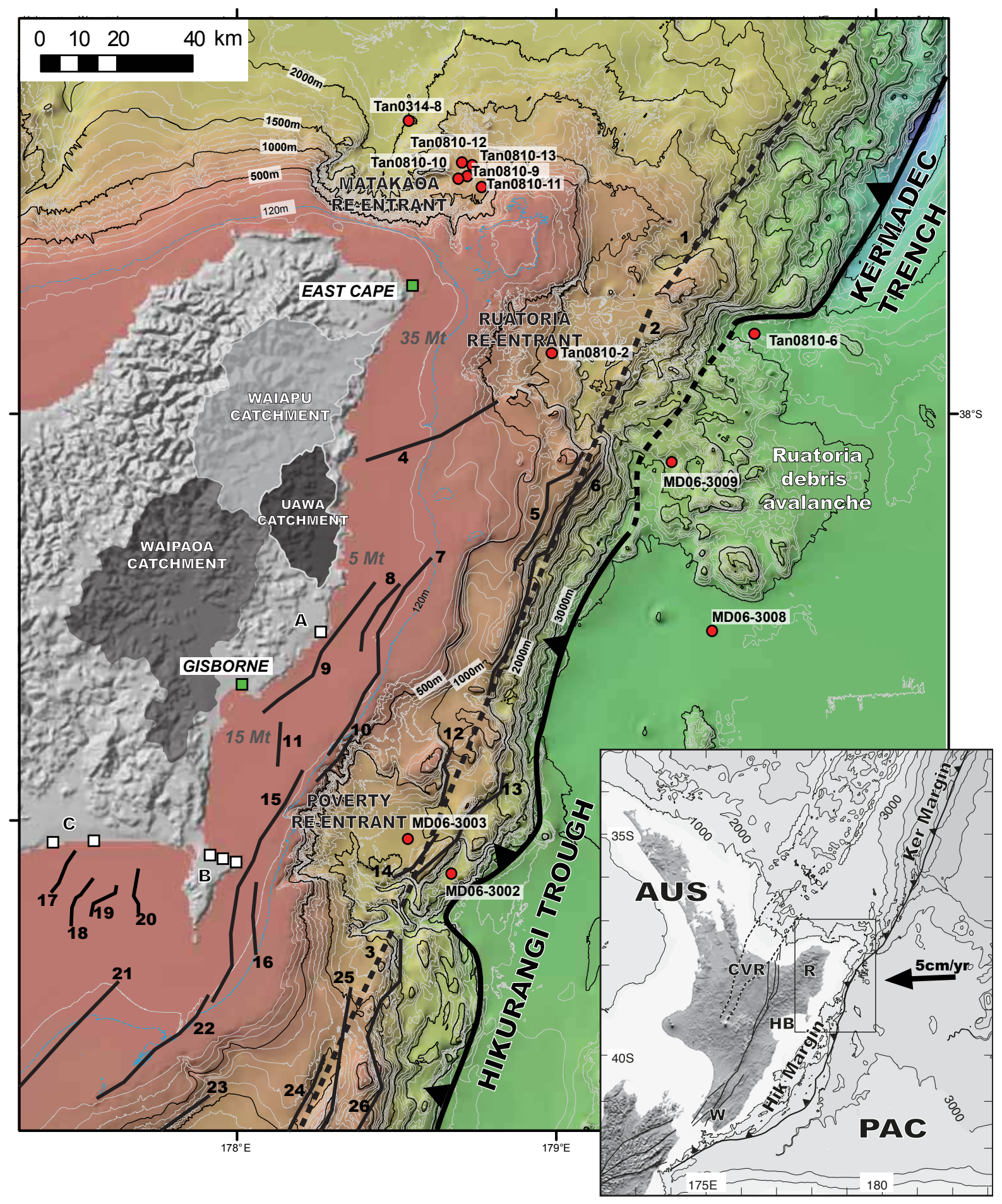

Figure 1 


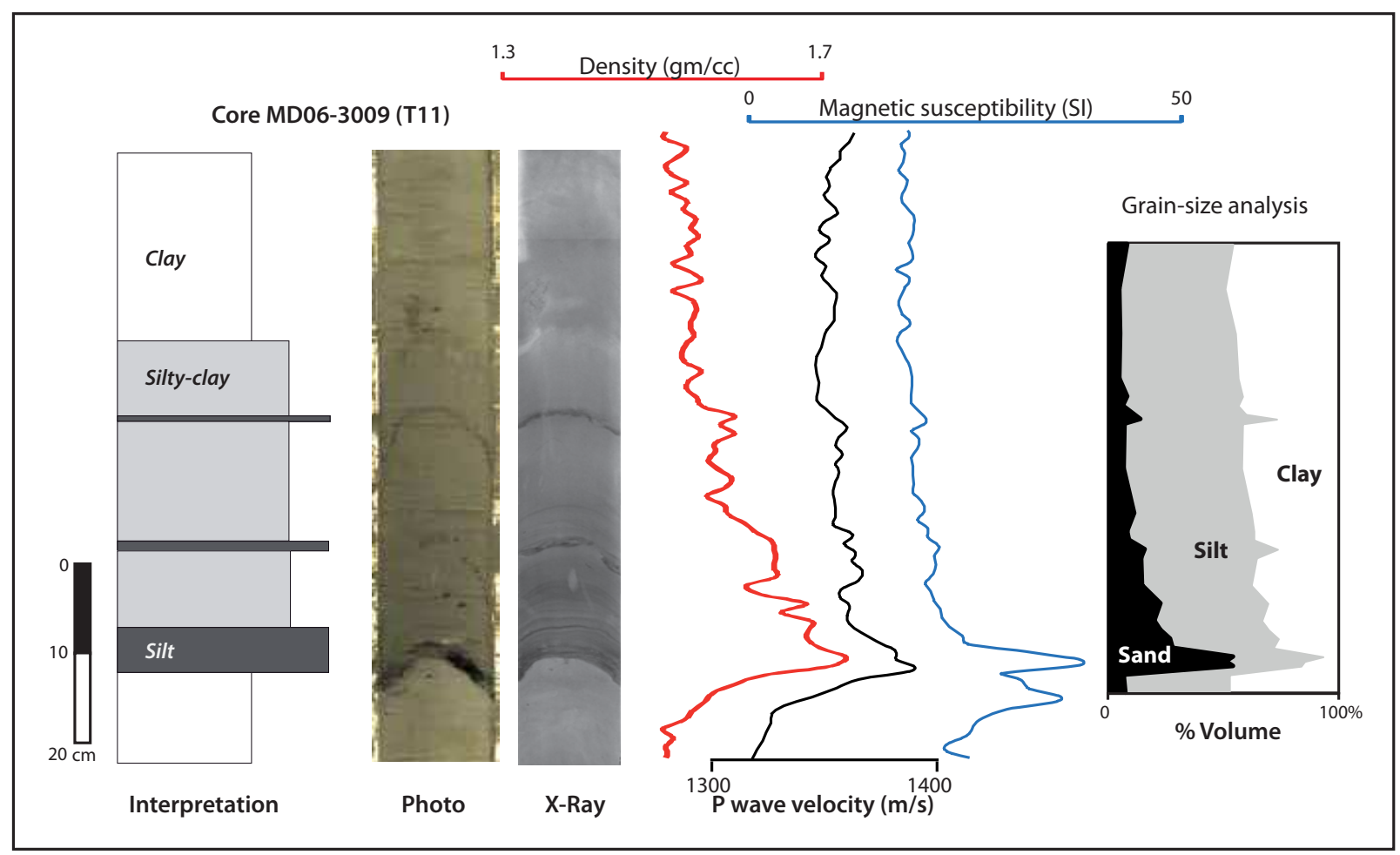

Figure 2 

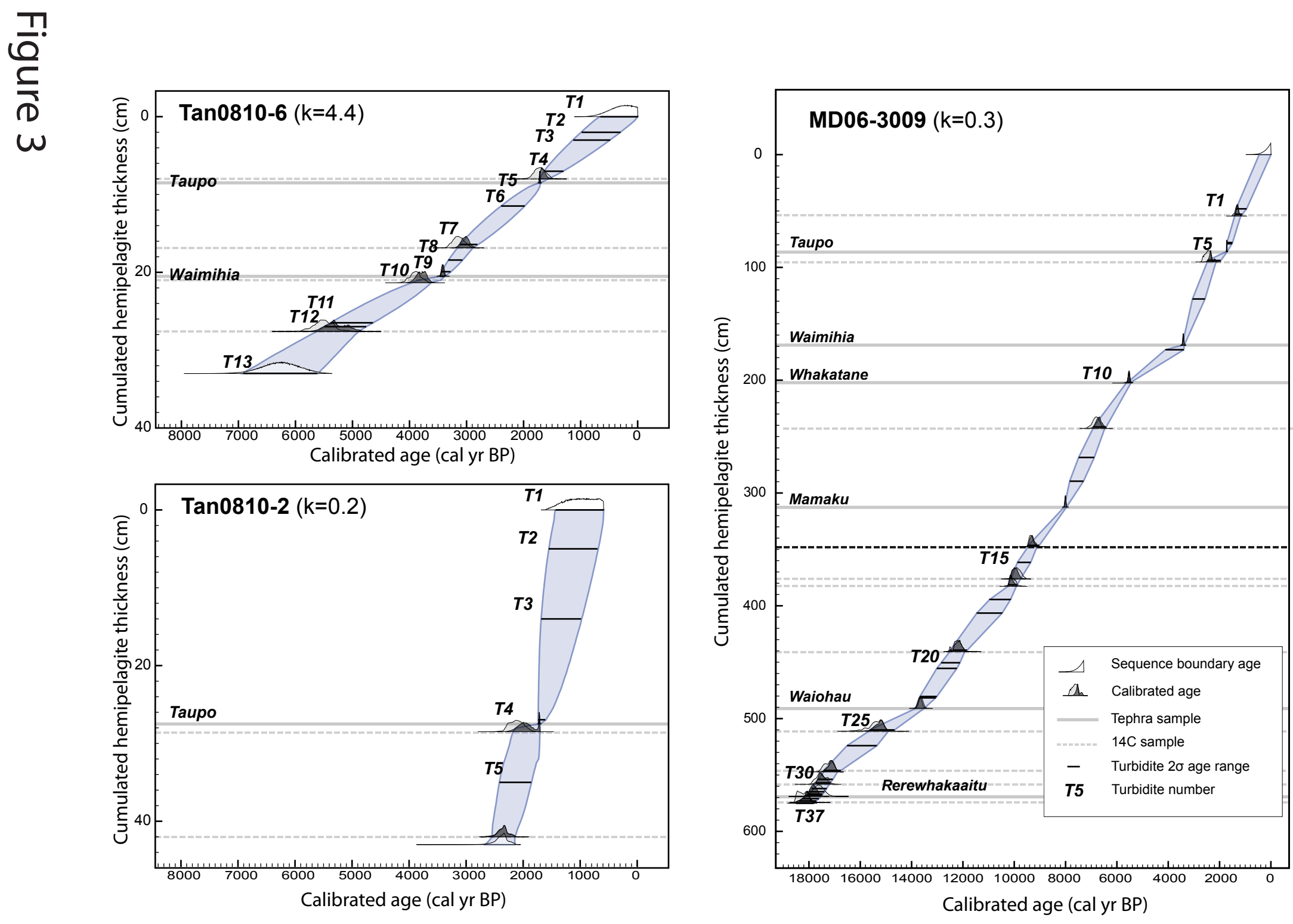


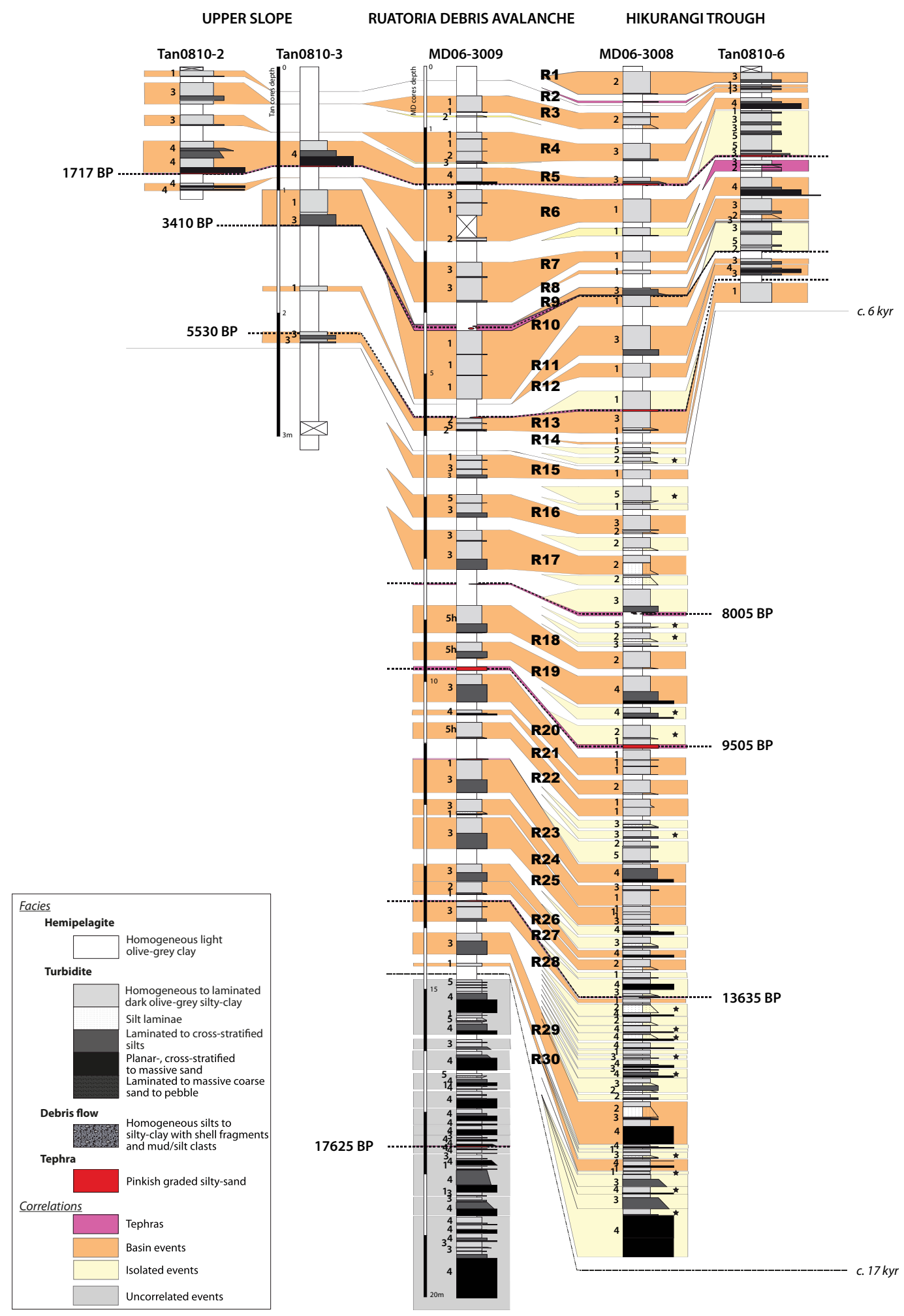

Figure 4 


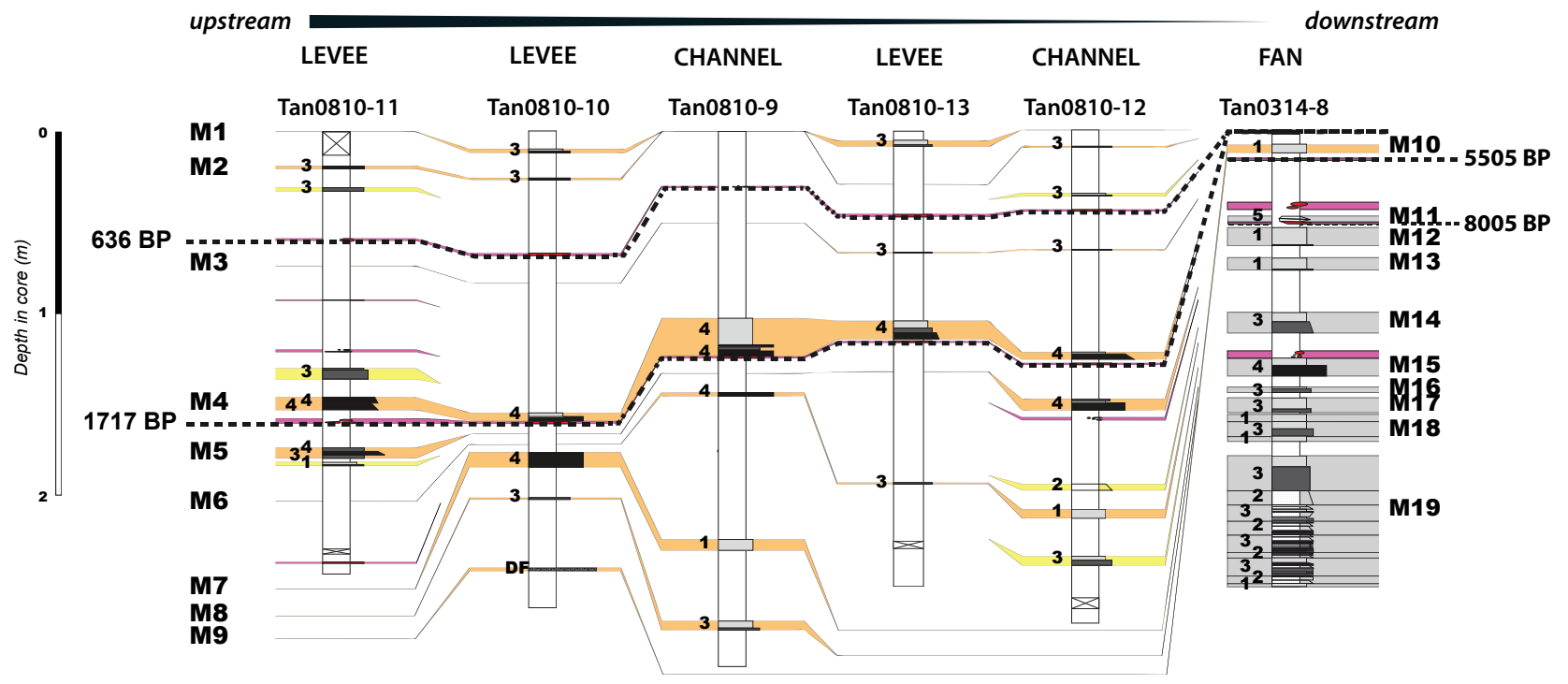

Figure 5 


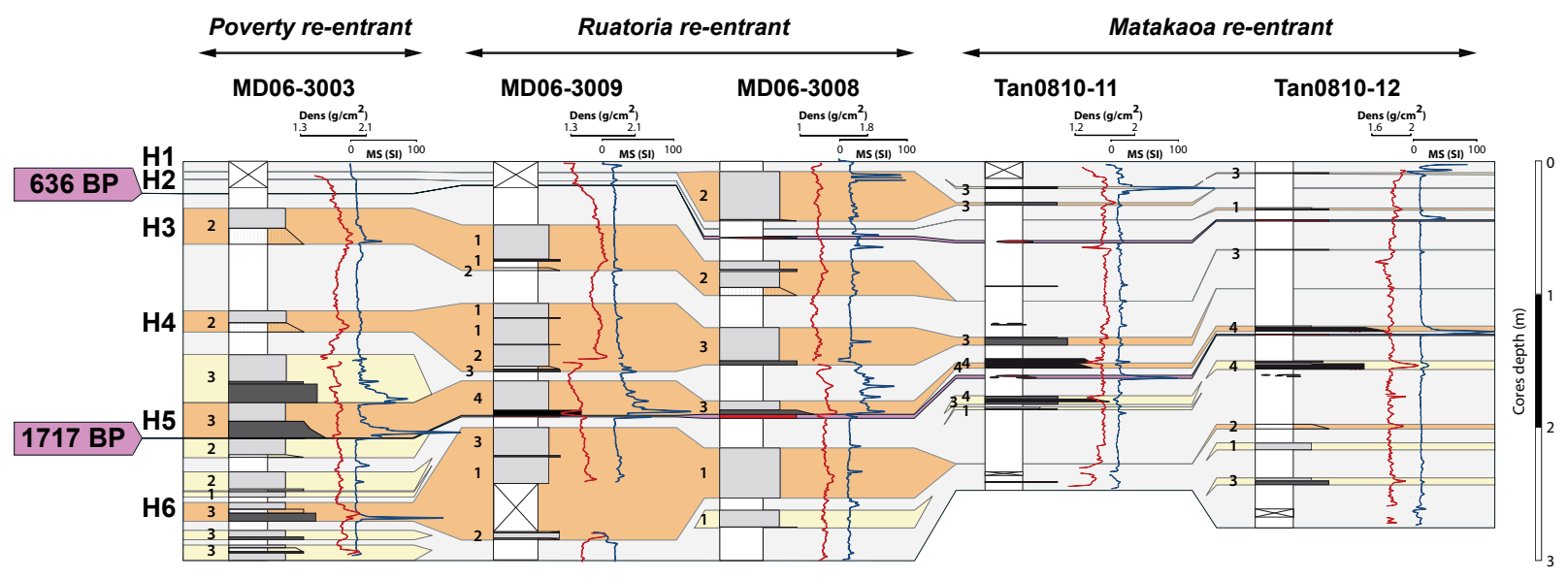

Figure 6 


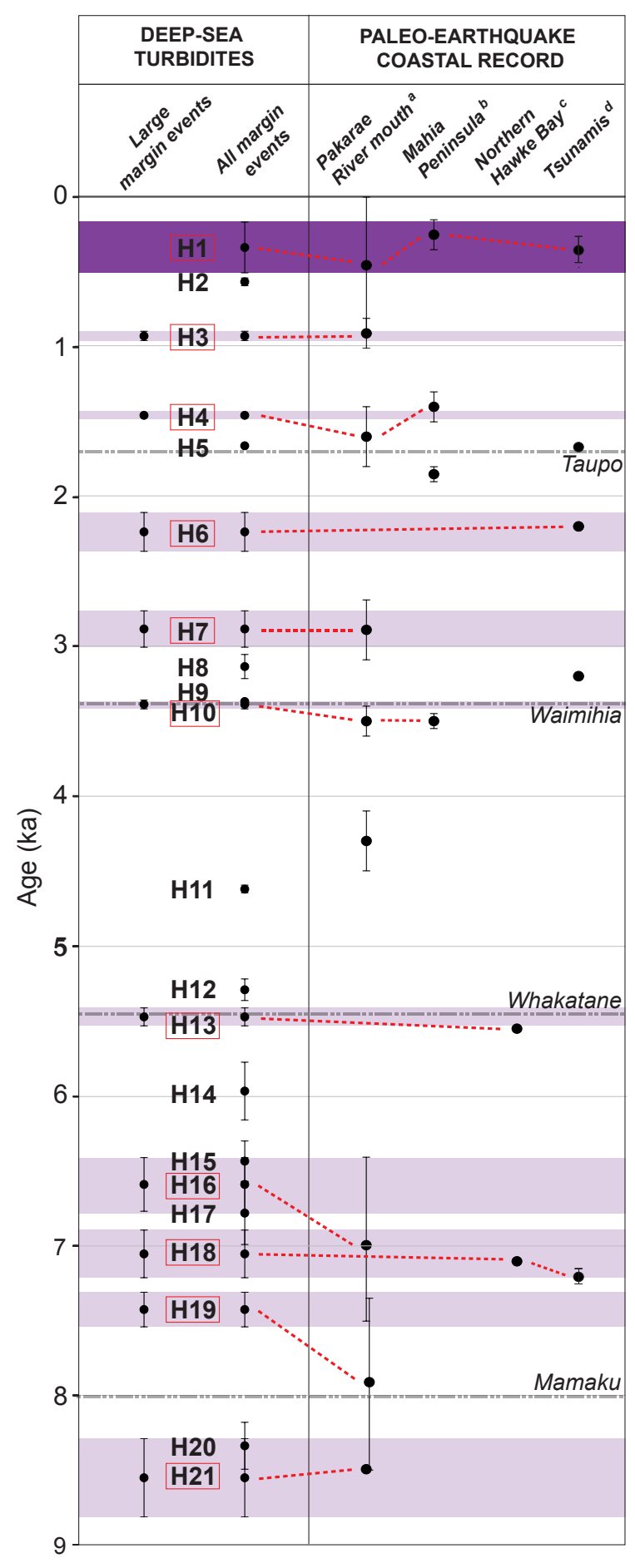

Figure 7 

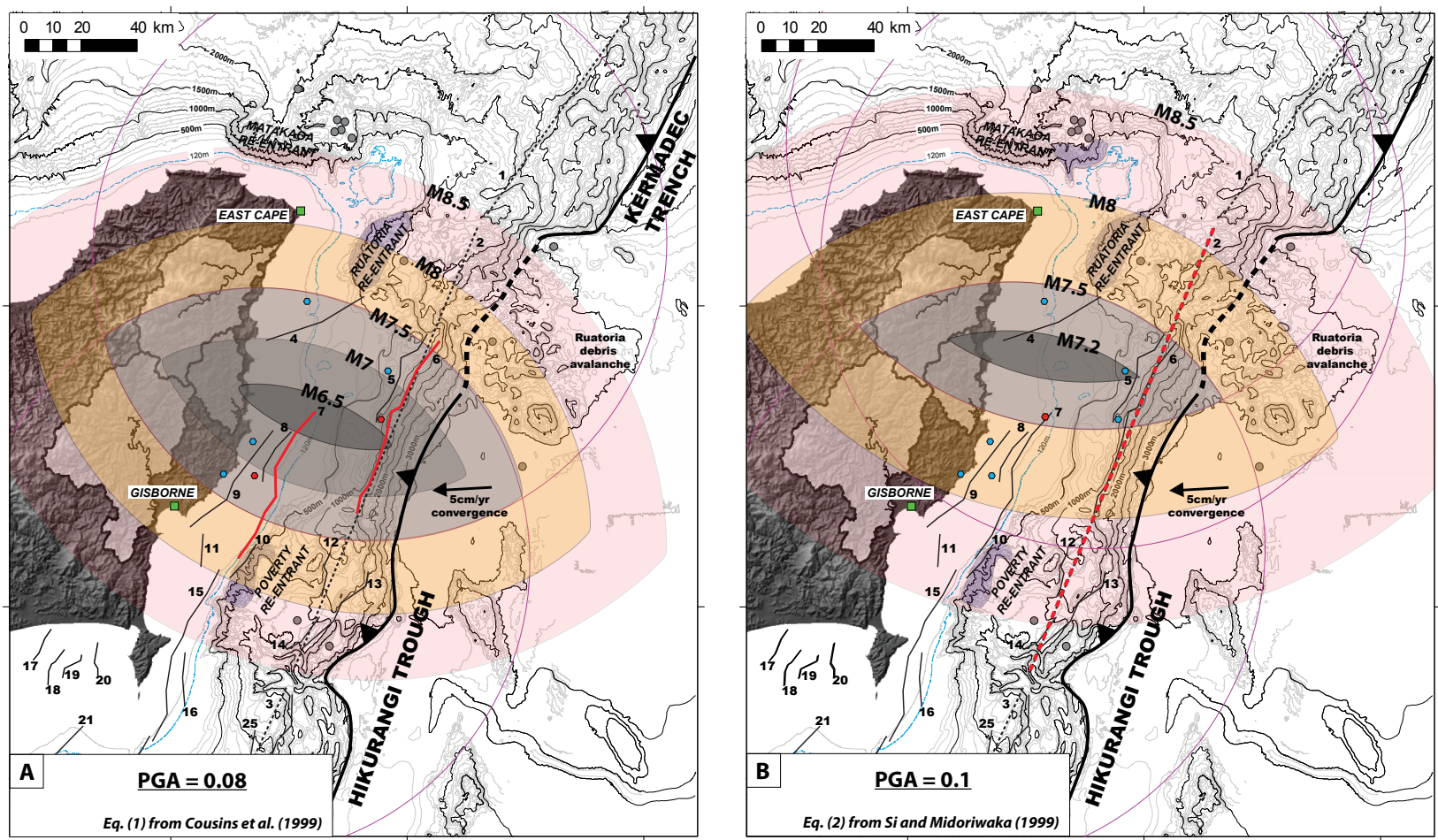

Figure 8 
A - Recurrence interval of earthquakes at the origin of all margin events $(n=41)$

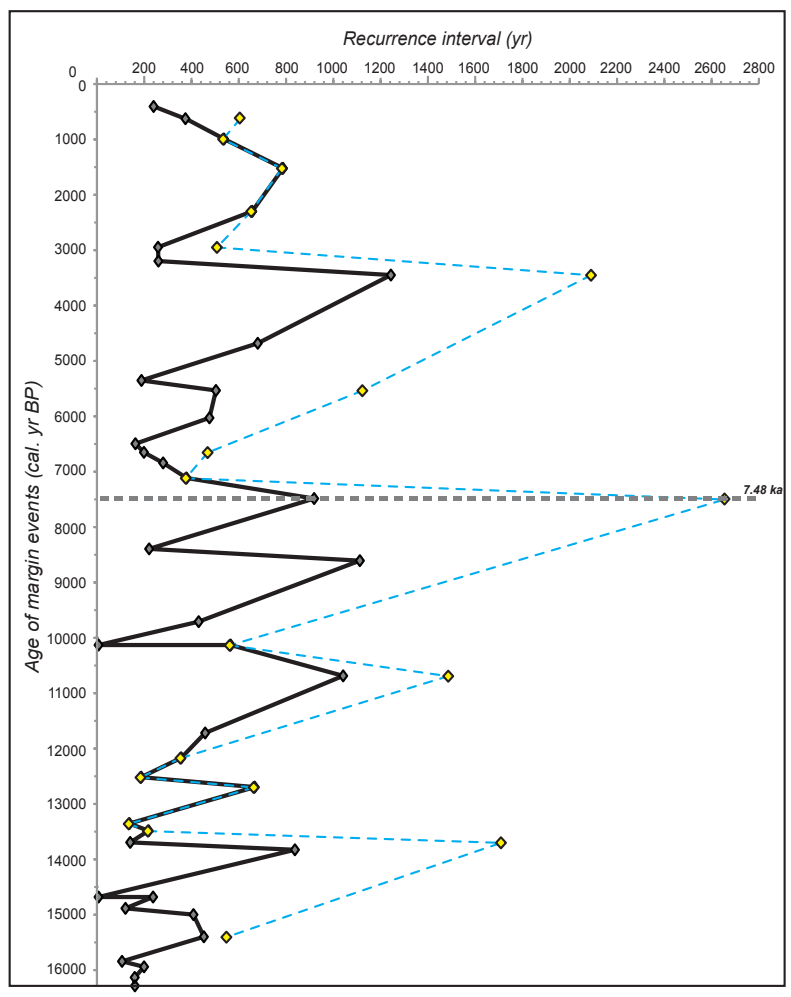

B - Recurrence interval of earthquakes at the origin of largemargin events $(n=20)$

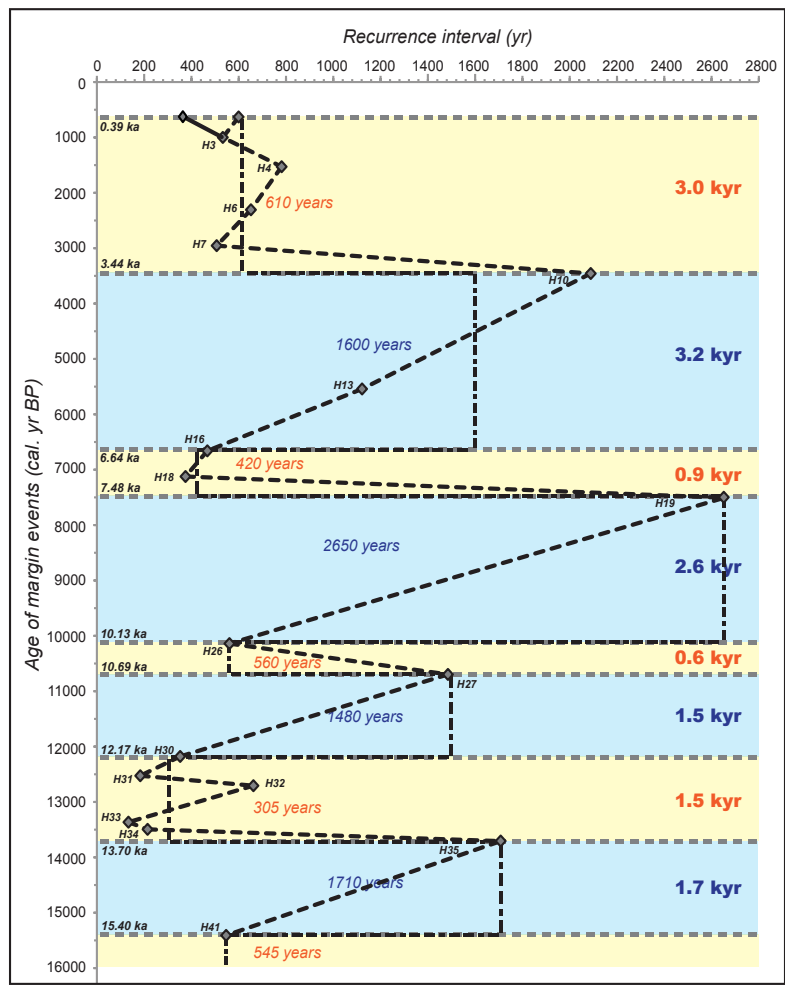

Figure 9 
A - Recurrence interval of earthquakes during the Late Holocene

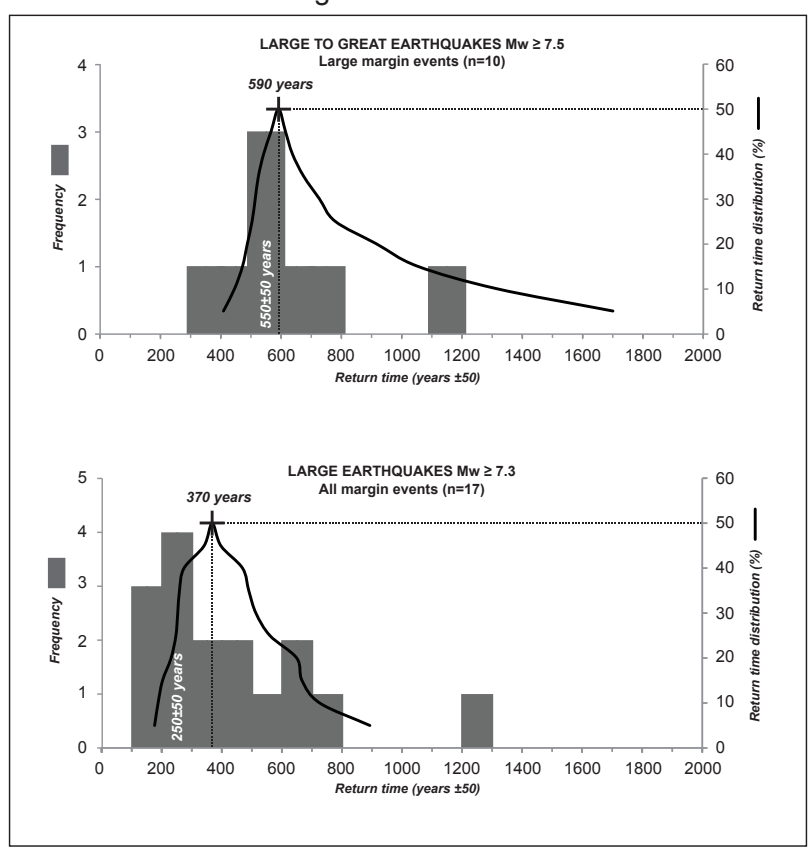

B - Recurrence interval of earthquakes

during the Late Pleistocene - Early Holocene

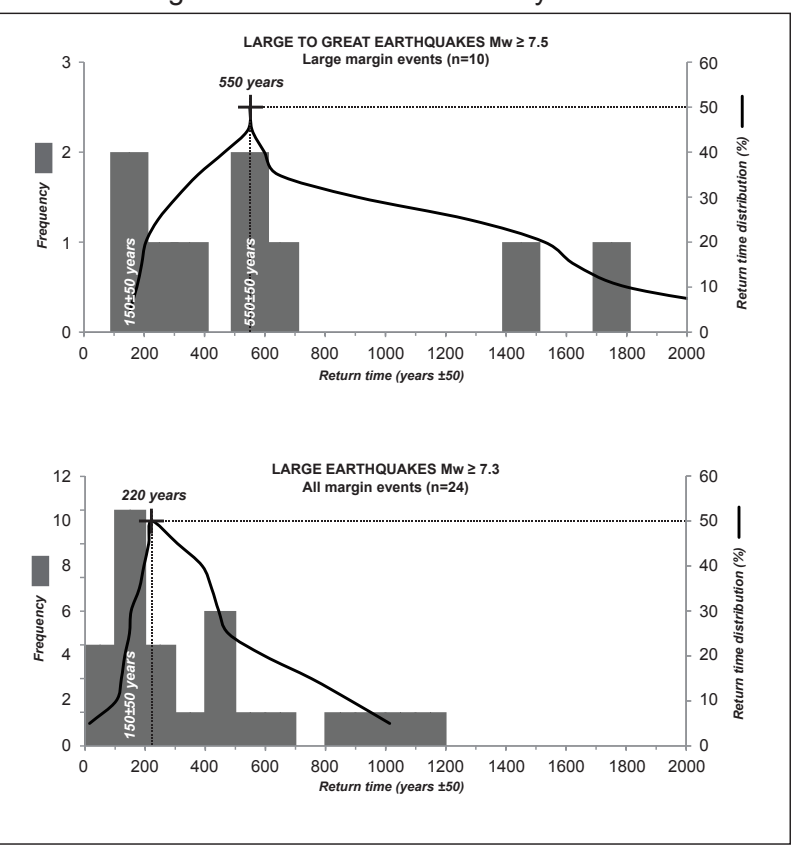

Figure 10 


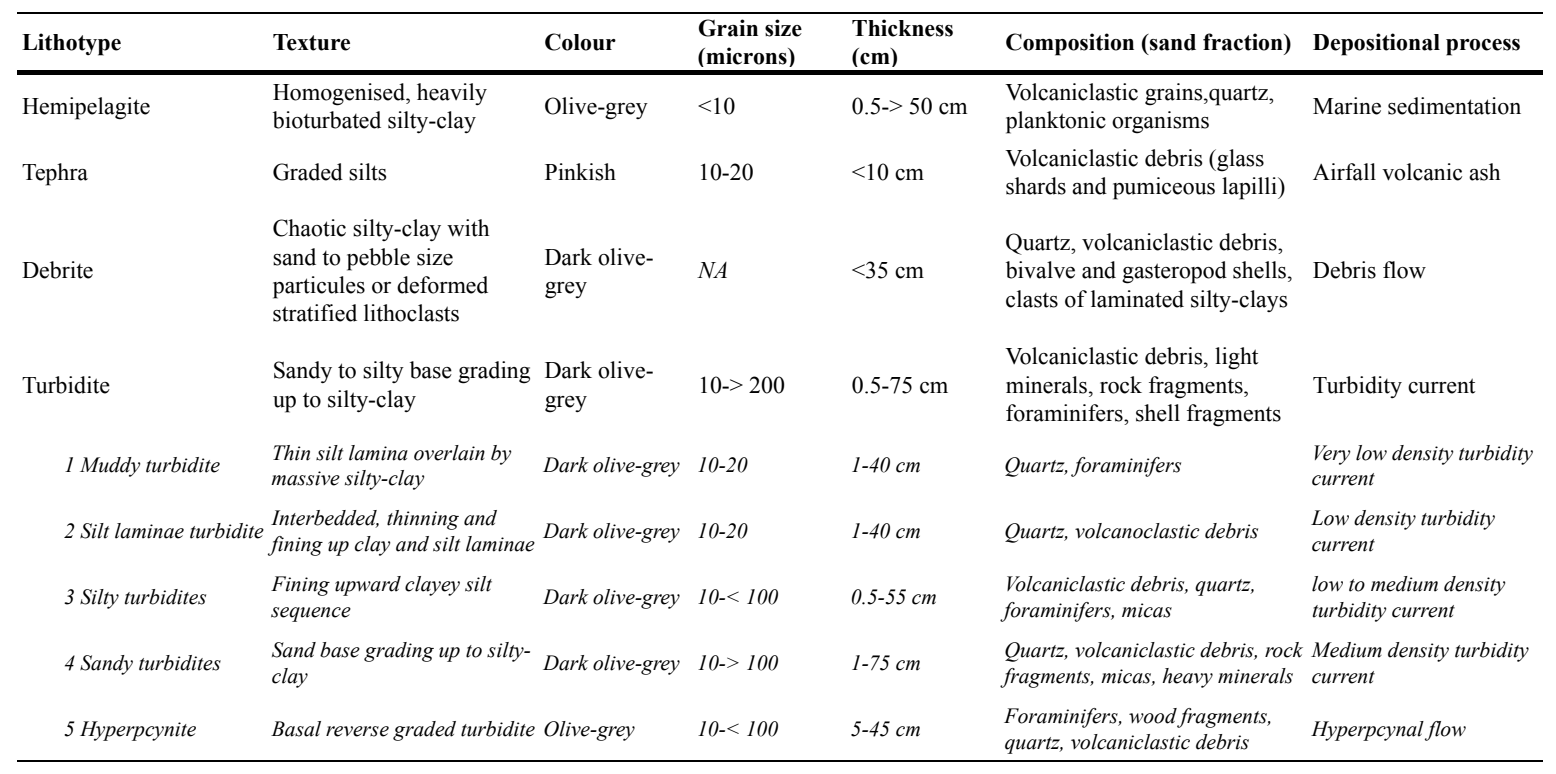

\section{Table 1}




\begin{tabular}{|c|c|c|c|c|c|c|c|c|c|c|c|c|c|}
\hline \multirow{2}{*}{ Core } & \multicolumn{2}{|c|}{ Longitude } & \multicolumn{2}{|c|}{ Latitude } & \multirow{2}{*}{$\begin{array}{c}\text { Water } \\
\text { depth }(\mathrm{m})\end{array}$} & \multirow{2}{*}{$\begin{array}{l}\text { Core length } \\
\quad(\mathrm{m})^{*}\end{array}$} & \multicolumn{2}{|c|}{ Composition } & \multirow{2}{*}{$\begin{array}{l}\text { Number of } \\
\text { gravity- } \\
\text { flow } \\
\text { deposits }\end{array}$} & \multicolumn{4}{|c|}{ Thickness of gravity-flow deposits (cm) } \\
\hline & deg. & $\min$. & deg. & $\min$. & & & $\mathrm{T}$ & $\mathrm{H}$ & & Min & $\operatorname{Max}$ & Mean & s.d. \\
\hline MD 06-3002 & 39 & 7.83 & 178 & 40.31 & 2305 & $20(12)$ & $75 \%$ & $25 \%$ & 100 & 1.5 & 22 & 7.6 & 4.4 \\
\hline MD 06-3003 & 39 & 2.79 & 178 & 32.17 & 1398 & 12.88 & $77 \%$ & $23 \%$ & 101 & 1 & 36 & 9.8 & 6.8 \\
\hline MD 06-3008 & 38 & 32.12 & 179 & 32.04 & 3520 & $25.4(19)$ & $75 \%$ & $25 \%$ & 89 & 2 & 48 & 16 & 10.8 \\
\hline MD 06-3009 & 38 & 7.02 & 177 & 21.69 & 2940 & 20 & $70 \%$ & $30 \%$ & 77 & 1 & 76 & 17.9 & 14.9 \\
\hline TAN0810-2 & 37 & 50.973 & 178 & 59.201 & 1078 & 1.65 & $60 \%$ & $40 \%$ & 8 & 2 & 18 & 8 & 4.8 \\
\hline TAN0810-3 & 37 & 52.691 & 178 & 57.289 & 1090 & 3.2 & $22 \%$ & $78 \%$ & 6 & 3 & 20 & 10.3 & 6.6 \\
\hline TAN0810-6 & 37 & 48.105 & 179 & 37.228 & 3400 & 1.8 & $82 \%$ & $18 \%$ & 25 & 1 & 18.5 & 6.1 & 4.1 \\
\hline TAN0314-8 & 37 & 16.088 & 178 & 32.29 & 2034 & 2.51 & $63 \%$ & $37 \%$ & 20 & 2 & 11.5 & 7 & 2.9 \\
\hline TAN0810-9 & 37 & 24.5876 & 178 & 43.108 & 1180 & 3.2 & $12 \%$ & $88 \%$ & 5 & 2 & 16 & 6.8 & 4.8 \\
\hline TAN0810-10 & 37 & 24.77 & 178 & 41.799 & 1159 & 2.2 & $8 \%$ & $92 \%$ & 6 & 1 & 8 & 3 & 2.5 \\
\hline TAN0810-11 & 37 & 26.1094 & 178 & 45.8894 & 1089 & 2.6 & $12 \%$ & $88 \%$ & 8 & 1.5 & 6 & 3.1 & 1.4 \\
\hline TAN0810-12 & 37 & 23.382 & 178 & 42.851 & 1255 & 2.75 & $11 \%$ & $89 \%$ & 8 & 0.5 & 6 & 3.3 & 2 \\
\hline TAN0810-13 & 37 & 23.55 & 178 & 44.054 & 1167 & 2.5 & $7 \%$ & $93 \%$ & 4 & 1 & 10 & 3.9 & 3.7 \\
\hline
\end{tabular}

*: full recovered length; when core deformation is too high, the used core length is given between brackets.

**: total number of turbidite layers identified in the core.

\section{Table 2}




\begin{tabular}{|c|c|c|c|c|c|c|c|c|}
\hline \multirow{2}{*}{ Re-entrant } & \multirow{2}{*}{ Core } & \multirow{2}{*}{$\begin{array}{c}\text { Core depth } \\
\text { (m) }\end{array}$} & \multicolumn{2}{|c|}{ Gamma density (g/cm2) } & \multicolumn{2}{|c|}{ Magnetic susceptibility (SI) } & \multicolumn{2}{|c|}{ P-Wave velocity $(\mathrm{m} / \mathrm{s})$} \\
\hline & & & $\mathbf{H}$ & $\mathbf{T}$ & $\mathbf{H}$ & $\mathbf{T}$ & $\mathbf{H}$ & $\mathbf{T}$ \\
\hline \multirow{3}{*}{ Ruatoria } & MD06-3009 & 2940 & $1.4-1.6$ & $1.4-2$ & $10-25$ & $15-100$ & $1300-1500$ & $1350-1700$ \\
\hline & MD06-3008 & 3520 & $1.1-1.4$ & $1.2-1.7$ & $10-25$ & $15-100$ & $1650-1700$ & $1775-1950$ \\
\hline & Tan0810-6 & 3400 & $1.7-1.8$ & $1.7-2$ & $10-25$ & $15-100$ & $1650-1700$ & $1700-1800$ \\
\hline \multirow{2}{*}{ Matakaoa } & Tan0810-10 to - & $1168 \pm 82$ & $1.6-1.8$ & $1.6-2$ & 10 & $10-100$ & $1225-1425$ & $1400-1550$ \\
\hline & Tan0314-8 & 2034 & 1.8 & $1.8-2.1$ & 15 & $15-50$ & 1225 & $1225-1375$ \\
\hline \multirow{2}{*}{ Poverty } & MD06-3003 & 1398 & 1.8 & $1.8-2.2$ & 10 & $10-100$ & 1300 & $1300-1500$ \\
\hline & MD06-3002 & 2305 & 1.8 & $1.8-2.2$ & 60 & $60-120$ & 1400 & $1400-1600$ \\
\hline
\end{tabular}

H: hemipelgite; T: turbidites

\section{Table 3}




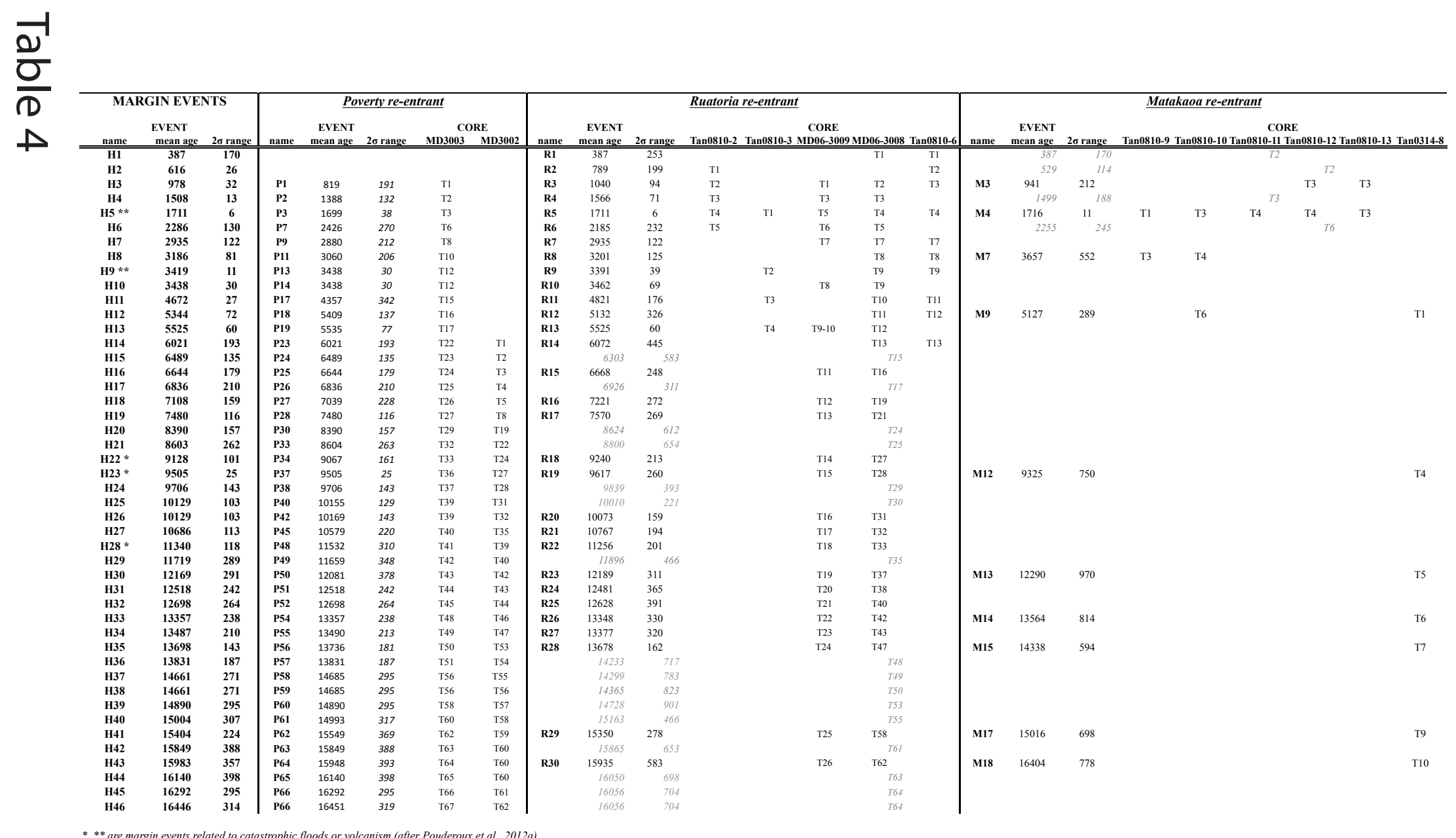


All margin events $(n=41)$

\begin{tabular}{|c|c|c|c|c|c|c|}
\hline \multirow[b]{2}{*}{ PGA } & \multicolumn{3}{|c|}{ Cousins et al. (1999) - Eq. (1) } & \multicolumn{3}{|c|}{ Si and Midoriwaka (1999) - Eq. (2) } \\
\hline & Faults * & $\mathbf{R I} * *$ & Mw range & Faults * & $\mathbf{R I} * *$ & Mw range \\
\hline 0.08 & $2 ; 6 ; 7$ & $390-460$ years & $7.3-8.4$ & $2 ; 6 ; 7$ & $390-460$ years & $7.3-8.4$ \\
\hline 0.1 & $2 ; 6$ & $890-1235$ years & $7.3-8.4$ & $2 ; 6 ; 7$ & $390-460$ years & 7.3-8.4 \\
\hline 0.15 & 2 & $1300-1670$ years & $8.2-8.4$ & 2 & $1300-1670$ years & $8.2-8.4$ \\
\hline
\end{tabular}

*: Numbers correspond to faults detailed in Table SM1; ** Recurrence intervals calculated for the duration of our turbidite record (16,060 years, from 390 to 16,450 yr BP) Average recurrence interval deduced from the turbidite record : 400 years

Large margin events $(n=20)$

\begin{tabular}{|c|c|c|c|c|c|c|}
\hline \multirow[b]{2}{*}{ PGA } & \multicolumn{3}{|c|}{ Cousins et al. (1999) - Eq. (1) } & \multicolumn{3}{|c|}{ Si and Midoriwaka (1999) - Eq. (2) } \\
\hline & Faults * & $\mathbf{R I} * *$ & Mw range & Faults * & $\mathbf{R I} * *$ & Mw range \\
\hline 0.08 & 2 & $1300-1670$ years & $8.2-8.4$ & $2 ; 6$ & $890-1235$ years & $7.3-8.4$ \\
\hline 0.1 & $\varnothing$ & $\varnothing$ & $\varnothing$ & 2 & $1300-1670$ years & $8.2-8.4$ \\
\hline 0.15 & $\varnothing$ & $\varnothing$ & $\varnothing$ & 2 & $1300-1670$ years & $8.2-8.4$ \\
\hline
\end{tabular}

*: Numbers correspond to faults detailed in Table SM; ** Recurrence intervals calculated for the duration of our turbidite record (16,060 years, from 390 to 16,450 yr BP) Average recurrence interval deduced from the turbidite record: 800 years

\section{Table 5}

